\title{
Animal models of major depressive disorder and the implications for drug discovery and development
}

Konstantin A. Demin ${ }^{\text {a,b }}$, Maxim Sysoev ${ }^{\text {c,d, }}$, Edina Wappler-Guzzettal ${ }^{1}$ Mamiko Koshiba ${ }^{\text {tu }}$, Gregory Oksenkrug ${ }^{\mathrm{n}}$, Cai Song ${ }^{\mathrm{o}}$, Brian Leonard ${ }^{\mathrm{p}}$, Matthew O. Parker ${ }^{\mathrm{r}}$, Brian Harvey ${ }^{\mathrm{s}}$, Li Tian ${ }^{\mathrm{t}}$, Tatyana V. Strekalova ${ }^{\mathrm{v}, \mathrm{w}, \mathrm{x}}$ and Allan V. Kalueffe,f,g,h,i,j,k,1*

anstitute of Experimental Medicine, Almazov National Medical Research Centre, St. Petersburg, Russia;

${ }^{\mathrm{b}}$ Institute of Translational Biomedicine, St. Petersburg State University, St. Petersburg, Russia; ${ }^{\mathrm{c}}$ Laboratory of Preclinical Bioscreening, Russian Research Center for Radiology and Surgical Technologies, Pesochny, Russia

${ }^{\mathrm{d}}$ Institute of Experimental Medicine, St. Petersburg, Russia

eSchool of Pharmacy, Southwest University, Chongqing, China;

fUral Federal University, Ekaterinburg, Russia;

${ }^{\mathrm{g} G r a n o v}$ Russian Research Center of Radiology and Surgical Technologies, St. Petersburg, Russia;

${ }^{\mathrm{h}}$ ZENEREI Research Center, Slidell, LA, USA

${ }^{i}$ Laboratory of Biological Psychiatry, Institute of Translational Biomedicine, St. Petersburg State University, St. Petersburg, Russia;

${ }^{k}$ Research Institute of Physiology and Basic Medicine, Novosibirsk, Russia;

IThe International Zebrafish Neuroscience Research Consortium (ZNRC), Slidell, LA, USA;

${ }^{\text {n}}$ Tuffts University medical School, Medford, MA, USA;

${ }^{\circ}$ Research Institute of Marine Drugs and Nutrition, Guangdong Ocean University, Zhanjiang, China;

${ }^{p}$ National University of Ireland, Galway, Ireland

${ }^{\mathrm{r}}$ Brain and Behaviour Lab, School of Pharmacy and Biomedical Science, University of Portsmouth, Portsmouth, UK

sDepartment of Pharmacology, University of Johannesburg, Johannesburg, South Africa tUniversity of Tartu, Tartu, Estonia

"National Center of Neurology and Psychiatry, 4-1-1, Ogawa-Higashi, Kodaira,Tokyo, Japan

vepartment of Normal Physiology, Laboratory of Psychiatric Neurobiology, Institute of Molecular Medicine, Sechenov First Moscow State Medical University, Moscow, Russia ${ }^{w}$ Laboratory of Cognitive Dysfunctions, Institute of General Pathology and Pathophysiology, Moscow, Russia

${ }^{x}$ Department of Neuroscience, Maastricht University, Maastricht, The Netherlands

\section{*Correspondence to:}

Dr. Allan V Kalueff, PhD, School of Pharmacy, Southwest University, Chongqing, China Email: avkalueff@gmail.com Tel/fax: 1-240-8999571 


\begin{abstract}
Depression is a highly debilitating syndrome that affects the global population and is associated with disabilities and suicide. Depression remains poorly studied and is often treatment resistant and recurrent. Thus, development of new therapies and drugs is needed in the field. Animal models are indispensable for translational biological psychiatry, and may advance the study of depression. While poor understating of psychiatric disorders (including depression) is slowing down further progress in the field, novel approaches continuously emerge that may help untangle disorder heterogeneity and blurred categories of contemporary diseases classification systems. Dividing core symptoms into easily translatable phenotypes is an effective way to reevaluate current paradigms. Also, other, more deep and complicated approaches and theories based on the endophenotype paradigm, such as 'cross-species trait genetic' and 'domain interplay concept' do continuously emerge to improve current paradigms and drug screening.
\end{abstract}

Keywords: depression, major depressive disorder, animal modeling, depression theories, depression pathogenesis, endophenotype 


\section{Introduction}

With over 300 million affected people globally, major depression is the largest cause of human disability ${ }^{1}$. Depression is a highly heterogeneous clinical disorder the diagnosis of which is complicated due to broad phenomenological criteria and poorly understood neurobiological bases $^{2-5}$. Associated with mood-, appetite-, sleep-, energy-, cognitive-, motor- and other deficits, depression symptoms may be grouped into several distinct neuropathological subtypes ${ }^{2}$ (Table 1). Thus, clinical or preclinical modeling of depression is complicated by the fact that we deal with multiple 'depressions ${ }^{\text {'6-8. }}$.

Another problem is that approximately $1 / 3$ of depressed patients are treatment-resistant, and the disorder has high rates of recurrence ${ }^{9-13}$ and comorbidity with other brain illnesses ${ }^{14-15}$ (Fig. 1). Furthermore, most existing antidepressant drugs have slow-onset action (weeks or months), and other available therapies, such as electro-convulsive therapies have significant sideeffects (e.g., amnesia) ${ }^{5}$. Thus, development of new therapeutic methods and antidepressants that address these limitations are desperately needed in the field ${ }^{5,16}$. However, this becomes a particularly challenging task, given the lack of pathophysiological understanding of this disease. Indeed, the most widely accepted monoamine imbalance hypotheses ${ }^{17-18}$ cannot account for limitations discussed above (delayed effects, treatment resistance), and recently proposed ‘inflammation' hypotheses ${ }^{19-21}$ do not account for major neurotransmitter deficits common for depression. Thus, further progress is urgently needed in the field, including conceptually new, paradigm-shift approaches and theories ${ }^{16,22-23}$.

Animal (experimental) models are an indispensable tool in translational and neuroscience research $^{23-24}$, relying on several well-recognized validity criteria, such as face (similarity of phenotypes), construct (similarity of neurobiological mechanisms) and predictive (similarity of treatment responsivity) validity ${ }^{10,25-27}$. For clear ethical, practical and historical reasons, most research utilizes rodents to study depression and other affective disorders ${ }^{10,28-34}$ (Fig. 2). Rodent models of depression are relatively well-established, and target different aspects of depression (Table 2), including stress ${ }^{35-40}$, genetics ${ }^{41-49}$, inflammation ${ }^{50-53}$ and drug responses ${ }^{54-56}$. Here, we 
recognize multiple challenges currently faced by the field of experimental depression models. The present report is a multi-lab effort, lead by the International Stress and Behavior Society (ISBS) Special Panel on experimental and translational depression models.

Many animal models of depression display homologous physiological and neurochemical responses. For example, stress-based models, such as chronic unpredictable stress, chronic social defeat stress, chronic restraint, prolonged social isolation and single prolonged stress, not only result in depression and anxiety-like behavioral phenotypes, as well as memory and sleep disturbances, but also increase plasma models of molecular biomarkers (e.g., interleukins IL-1 $\beta$, IL-6, TNF- $\alpha$ ) and decrease neurotrophins (e.g., BDNF and NGF) in the brain - the effects which can be reversed by antidepressant treatment ${ }^{23,35-40,57-64}$. Since stress is the most common factor of depression onset and progression ${ }^{26,57}$, high face and construct validity, predictive power and relative simplicity make stress-based models widely used to model depression ${ }^{23,65}$.

While genetic vulnerability plays a role in $35-40 \%$ of variance in depression ${ }^{66}$, human genetic analyses often fail to identify reproducible genetic loci that contribute significantly to depression ${ }^{67}$. Indeed, reflecting the multi-factorial nature of depression, recent genetic studies reveal deep connections between psychiatric disorders, including depression, and immune factors, neuronal signaling, synaptic density and histone cascades, suggesting the presence of larger risk clusters in these pathways ${ }^{68}$. Genetic rodent models indicate the role of serotonergic ${ }^{41-44}$, noradrenergic ${ }^{45-46,69-70}$, dopaminergic ${ }^{71-72}$, opioid ${ }^{73-74}$, GABA-ergic ${ }^{10,75-76}$ and glutamatergic ${ }^{77-80}$ systems in depression-like behavior. However, translation of these models into human depression faces difficulties due to restriction of knockouts to one gene and, at the same time, simultaneous involvement of most core neurotransmitter systems in animal depression-associated behavior. Moreover, depression is also recognized as a result of gene $\mathrm{x}$ environment interactions (GxE), acting as a susceptibility and a trigger, respectively ${ }^{81-82}$.

There are also other behavioral paradigms that are tightly related to depression-like behavior. For example, sickness behavior (Table 2) is associated with depressive behavior and usually evolves as acute sickness reaction to an inflammatory agent, followed by gradually 
increasing depression-like behavior, including social withdrawal and motor retardation ${ }^{31}$. This effect involves cytokine signaling pathways ${ }^{31}$ and can be induced by a wide range of agents, including polysaccharide (LPS) ${ }^{83-89}$, viral mimetic polyriboinosinic-polyribocytidylic acid (Poly $\mathrm{I}: \mathrm{C})^{90}$, interferon (IFN)- $\alpha^{91-93}$ and bacillus Calmette-Guerin (BCG) ${ }^{94-95}$. Some overlaps between drug withdrawal and depression also exist ${ }^{96}$ and have been reported in rodents for cocaine, amphetamine, ethanol, morphine and nicotine ${ }^{54-56}$ (also note hypomania following antidepressant discontinuation both in clinical practice and animal models ${ }^{97-98}$ ).

Now that there are good models of inducing depression in animals, the next logical question is whether we have reliable methods to assess animal depression-like behaviors? This question is also important because antidepressant drug discovery heavily relies on such tests. The core depression-related symptoms that can be accessed in rodents include anhedonia, eating and sleep disturbances, agitation or retardation of motor activity, cognitive deficits, energy loss, despair as well as neuroimmune and neuroendocrine disturbances ${ }^{10,24,99-116}$. However, these symptoms are not specific to depression, and can often occur in other psychiatric and other diseases. For example, the forced swim test $(\mathrm{FST})^{114,116-117}$ and the tail suspension test $(\mathrm{TST})^{112 \text {, }}$ 118 are commonly used to access behavioral despair in rodents. However, albeit considered one of the main depression-like states, despair is not unique for depression and can be observed in other models $^{119}$. Thus, a wider range of tests and/or complex batteries of behavioral tests that address distinct domains should be used to increase rates of successful antidepressant drugs determination.

\section{Non-rodent models of depression}

While rodent depression-like states and effects of antidepressants have long been recognized, many other model species exist that can be used to target evolutionarily conserved depression-related states. For example, non-human primates can bridge a gap between rodent and human models ${ }^{120-121}$, whereas zebrafish models can provide novel complementary data (in addition to rodent models) that may untangle high heterogeneity of depression by focusing on its core, evolutionarily conserved roots (Table 3). Common models of depression in non-human primates involve maternal ${ }^{122-123}$ or social separation ${ }^{124-125}$ and reflect various aspects of human 
depression $^{126}$, such as despair, anhedonia and lethargy ${ }^{127}$. Such models are validated pharmacologically, and, interestingly, antidepressants seem to have similar time course to that observed clinically (unlike in some rodent models) ${ }^{128-129}$. Other drugs, including amphetamine and ethanol, exert antidepressant effects in non-human primates ${ }^{127,130}$, whereas g-methyl-p-tyrosine or reserpine reduce social interactions and locomotion, as well as induce anhedonia-like lack of environmental interaction ${ }^{126,131}$. Interestingly, depressive behaviors can occur in macaques spontaneously ${ }^{132}$, strikingly reproducing human depression. Likewise, neurochemical alterations in primate oxytocin, monoamines and their metabolites also resemble alterations observed in depressed patients ${ }^{133-139}$. Finally, non-human primates are also used to model depressive behavior in chronic stress ${ }^{140}$ and cytokine-induced depression ${ }^{141}$.

Among lower vertebrates, zebrafish represent an interesting model organism to study complex CNS states ${ }^{142-146}$, including anxiety, addiction, autism, obsessive-compulsive states and depression ${ }^{142-146}$. Similarly to rodents, zebrafish depression-like states can be induced using stress, genetic or pharmacological manipulations ${ }^{147}$ (Table 3). For instance, zebrafish chronic stress exposure elevates anxiety-related behavior, increases whole-body cortisol, IL-1 $\beta$, IL-6, adenosine, $\mathrm{mr}$, gr $\alpha, \operatorname{gr} \beta$, bdnf in telencephalon, $\mathrm{CRH}$, calcineurine, pCREB levels in brain, alters dendritic spines, reduces weight, and lowers dopamine and 5-HIAA levels ${ }^{148-153}$. Importantly, many of these effects can be corrected by antidepressant treatment ${ }^{151}$, thereby showing highly homologous chronic stress responses to those observed in rodents and humans. Moreover, zebrafish depression models differ from those in mammals (e.g., $b d n f / B D N F$ expression is often reduced in human and rodent depression models ${ }^{151}$ ), therefore providing not a "smaller mouse" model, but a truly complementary tool to study specific aspects of depression pathogenesis in-vivo.

While zebrafish possess some features that may cumulatively surpass advantages those of rodents ${ }^{154}$, its use in biological psychiatry is still developing, and therefore meets obstacles, challenges and skepticism. For example, it is still unclear how to properly distinguish zebrafish anxiety-like and depression-like phenotypes (if they are distinct at all) ${ }^{147}$, thus necessitating further 
deep phenotyping and developing of tests that can access more precisely various features of experimental depression.

\section{Theories of depression pathogenesis and new trends}

From 1948, when serotonin was first isolated, purified and identified as a monoamine ${ }^{155-}$ ${ }^{156}$, and 1969, when it was first linked to depression ${ }^{155}$, the field has clearly moved a long way. For example, there is a great diversity of serotonin receptors that can produce different effects depending on neuron type and cellular localization. Since $5-\mathrm{HT}_{1 \mathrm{~A}}$ agonists exert anxiolytic and antidepressant properties, it has been hypothesized that this type of receptor plays a role in developing depression. Postnatal antidepressant treatment can result in anhedonia, anxiety, increased (learned?) helplessness and other depression-related disturbances in adult rodents ${ }^{113,157-}$ ${ }^{158}$, whereas 5-HT $1 \mathrm{~A}$ knockout in mice display antidepressant-like behavior ${ }^{29,} 159-160$ and serotonin transporter knockout rodents display anxiety-like and higher stress vulnerability ${ }^{41-44}$.

Another hypothesis of depression is based upon inflammation caused by stress, as the expression of IL-1 $\beta$, IL-6, TNF- $\alpha$ and IFN- $\gamma$ genes were significantly higher in patients with major depression ${ }^{161-162}$. Furthermore, elevated stress hormones can impact the expression of several neurotrophic factors, thus influencing on neuroplasticity, which is impaired in depressed patients $^{161}$. Likewise, the hypothalamic-pituitary-adrenal (HPA) axis function is altered in depressed patients as well as in depressed rodent models, and reversed by antidepressant treatment $^{161}$. Likewise, disturbances of affective spectrum can occur after exposure to inflammatory agents (e.g., lipopolysaccharide (LPS) $)^{83-86}$, viral mimetic polyriboinosinicpolyribocytidylic acid ${ }^{90}$ and some autoantibodies ${ }^{163}$ ) or as a result of genetic manipulations of pro/anti-inflammation-related genes (e.g., $I L-10^{51-53}$ and $T N F-\alpha$ knockout models ${ }^{50}$ ). In line with this, anti-inflammatory agents can reduce depressive symptoms in humans ${ }^{164}$ and animals. For example, an anti-inflammatory microglia inhibitor antibiotic minocycline prevents LPS-induced increase in cytokines expression and indoleamine 2,3 dioxygenase (IDO, the tryptophan-degrading enzyme), blocking both sickness- and depression-like behavior in mice ${ }^{165}$. Interestingly, IDO antagonist 1-methyl-D,L- tryptophan exposure does not alter LPS- and Bacillus Calmette-Guerin 
(BCG)-induced proinflammatory cytokines and sickness-like, but reduces depression-like behavior $^{95,165}$, suggesting that novel anti-inflammatory agents can be screened for further use in depression treatment.

Aberrant GABA neurotransmission has also been linked to depression, as major depression is associated with GABRA1, GABRA5, GABRA6 and GABRG2 genes, and childhood mood disorders - with a male-specific polymorphism of the GABRD gene ${ }^{161}$. Consistent with this, major depression is generally accompanied by reduced GABA levels, which can be restored by conventional antidepressant treatments ${ }^{161}$. Interestingly, genetic modifications of GABAassociated proteins may affect anxiety and depression in different ways, since the glutamate decarboxylase (GAD65) knockout and GABA-B1 knockout display high anxiety-like but lower depression-like behaviors ${ }^{10,75-76}$, thereby providing a potentially valuable tool to dissect these two commonly comorbid (and frequently overlapping) conditions.

The reduction in astrocyte function and increased microglial activity and related markers are key features of major depression ${ }^{166-168}$. Indeed, astrocytes are crucial to neuron microenvironment due to their role in glucose metabolism, blood-brain barrier, neurotransmitteruptake, and synaptic development and maturation ${ }^{169-171}$. Both rodent models and human postmortem studies strongly support this hypothesis. For example, rats exposed to maternal separation have lower density of astrocytes in the medial prefrontal cortex ${ }^{172}$, and chronic social defeat reduces astrocyte count in various brain regions (prefrontal/frontal cortex, hippocampus and amygdala), lowering the levels of GFAP protein, an astrocyte marker ${ }^{173-174}$. Likewise, selective lesion of glial astrocytes by infusing L- $\alpha$ aminoadipic acid into rodent prefrontal cortex induces depressive-like behaviors ${ }^{175-176}$.

Recently, the role of gut microbiota in affective disorders has been recognized ${ }^{177}$ to modulate multiple neural, endocrine and immune mechanisms ${ }^{178}$, as shown using germ-free animals, bacterial infections or probiotics ${ }^{177}$. Indeed, germ-free rodents display increased anxiety${ }^{179-180}$ and depression-like behaviors ${ }^{181}$, as well as elevated noradrenaline, dopamine and serotonin turnover in the striatum ${ }^{182}$. In contrast, treating germ-free animals with probiotics lowers their 
anxiety and depression-like behaviors ${ }^{183-185}$, currently considered as psychobiotics - live organisms that, when ingested in adequate amounts, produce a health benefit in patients suffering from psychiatric illness ${ }^{186}$. Complementing gut microbiome involvement, depression is also linked to metabolic disorders, especially obesity and diabetes ${ }^{187-192}$. While the exact mechanisms underlying this link remain unclear, some of the linked conditions, such as type 2 diabetes, may involve shared pathogenetic mechanisms including chronic activation of immune and neuroendocrine parhways ${ }^{192}$. Animal studies are consistent with clinical data, since the Spontaneously Diabetic Torii (SDT) fatty rat model for type 2 diabetes shows increased depressive-like behavior, hyperlocomotion, higher basal corticosterone levels, lower serotonin and glutamate in prefrontal cortex, and higher GABA and glutamate levels in the hippocampus ${ }^{193}$. Similar depression-like behavior can be observed in diabetes induced by streptozotocin in rats and reversed by antidepressant treatment ${ }^{194}$. Some zebrafish models of diabetes and metabolic conditions also evoke anxiety-like behavior ${ }^{195-196}$.

\section{Conclusion}

Depression-like behavioral phenotypes vary widely between strains and species, and therefore cross-strain/species translations of data should be performed carefully ${ }^{197}$. Furthermore, individual differences in animal models also exist, and must be considered ${ }^{198}$. In fact, rodents exhibit a wide population variety in depression-like behaviors, and can be selectively bred for depression-like traits (e.g., Flinders Sensitive Line, Swim Low-Active and Helpless Rouen strains) 26, 199-213. Another important point to consider is environmental characteristics, since environmental enrichment and impoverishment can influence individual affective phenotypes ${ }^{214}$, and similar environmental modulation exists in animal depression models ${ }^{215-218}$. As individual differences exist in evolutionarily distant species, such as rodents and zebrafish ${ }^{219-223}$, individual behavioral, genetic and environmental factors must be monitored, to ensure correct interpretation of findings.

Recently, special attention has been given to drugs with putative rapid-acting antidepressant effects, affecting even patients resistant to conventional antidepressant treatments. 
For example, the NMDA receptor antagonist ketamine ${ }^{224}$ within days reduces depressive symptoms $^{225-228}$ and suicidal thoughts ${ }^{229}$ in patients, and exerts similar antidepressant effects in rodent FST, TST, inflammation-, stress- and learned helplessness-related models ${ }^{230-253}$.

Ideally, modeling depression or other mental disorders would need to recreate the etiologic process in animals, thus replicating not only specific individual phenotypes of interest, but a wider spectrum of neural and behavioral features of the disorder in question ${ }^{254}$. Given the fact that a model by itself is not a perfect replication of the condition studied, not all criteria can be met in a single model. Thus, combination of different models can more accurately address the condition of interest. Such cross-species paradigm can help understand the most common (and therefore core) features of diseases, as well as properly characterize distinct profiles observed in different species. Multispecies models of psychiatric diseases can introduce us to a principally new view of diseases in which neurobiological constructs play a leading role in pathogenesis. However, such models are yet to emerge and will rely on larger and more extensive cross-species studies.

\section{Expert Opinion}

\section{Endophenotype-driven approaches as a locomotive for innovations in the field}

While the lack of understating of pathogenesis of depression and other psychiatric disorders slows down further progress in the field, novel approaches continuously emerge ${ }^{255}$. For example, a radical rethinking of current taxonomies is required for deeper understanding of psychiatric disorders ${ }^{256-258}$. Endophenotype strategy reduces complex psychiatric conditions into directly measurable neurophysiological, neuropsychological, biochemical, endocrine, neuroanatomical or cognitive components ${ }^{259-261}$. However, this approach is not sufficient to overcome limitations that emerge in the field, necessitating further strategies to bridge its translational and cross-disciplinary gaps ${ }^{262-264}$. For example, the "cross-species trait genetic" approach postulates that simple behavioral endophenotypes should be conserved between species, including humans ${ }^{264}$. However, the 'spectrum' nature of CNS disorders and their overlapping endophenotypes, behavioral symptoms and biomarkers should also be considered ${ }^{262-263}$. Addressing this need, the "domain interplay" concept was suggested to further optimize animal 
modeling of CNS disorders ${ }^{262}$. Rather than simply focusing on specific behaviors or genes, this concept emphasizes the importance of analyzing several overlapping behavioral endophenotypes and interplay/dynamics between them ${ }^{262}$.

For a rigorous and thorough animal modeling of depression, new approaches also necessitate higher-throughput protocols and test batteries ${ }^{265-267}$. While common strategies utilize various specific tests to access key behavioral features of depression, another 'smart' approach may involve 'hybrid' behavioral models to speed up behavioral characterization ${ }^{268}$. Such hybridizing approach assesses several different domains in the same test, or combines several single-domain tests in the way that maximizes the spectrum of simultaneously or collectively observed phenotypes per trial ${ }^{268}$. For example, FST may be performed as part of the Morris Water maze, a well-established hippocampal memory test, thereby enabling a simultaneous assessment of both despair and cognitive responses related to depression ${ }^{268}$. Likewise, further hybridization can be achieved by examining post-swimming self-grooming and locomotor behavior in a subsequently run open field (novelty-based) or small observation box, to detect phenotype associated with depression-like behavioral perseverations ${ }^{269}$ and/or examining per-minute behavioral activity in these tests, to study habituation (a working memory-related phenotypes) reflecting cognitive alterations in depression ${ }^{268,270 .}$

Another important aspect to consider is the overall trajectory of the disorder. Indeed, neuropsychiatric phenomena are not instant, and cannot be treated separately from their development and dynamics ${ }^{271-272}$. Albeit markedly understudied, dynamic models in biological psychiatry have recently received increasing attention. For example, the 'interlinking genes' approach can be used to address this problem ${ }^{262-263}$ since various disordered endophenotypes interact with each other, and may share common molecular 'crosstalk' mechanisms that, although not influencing the phenotypes by themselves, can confer their interrelatedness ${ }^{262-263}$. Example of dynamic interactions in this case can be depression-like phenotypes developing during chronic stress after an initial anxiety-like pathological state has occurred. Specifically, the chronic social defeat model uses conspecific agonistic interactions between mice (most commonly, C57BL/6J) 
to produce a lasting experience of defeat in chronically losing mice ${ }^{273-275}$. The model is known to induce both anxiety-like and depression-like phenotypes ${ }^{276}$. At the same time, while increased anxiety can be observed at 3-10 days of chronic stress ${ }^{277}$, depression-like phenotype is usually induced after 20-21 days of such antagonistic interactions ${ }^{278}$. Therefore, development of anxiety precedes the development of depression in the chronic social stress model; interestingly, this is often true for depressed patients, as anxiety can trigger depression in $15-33 \%$ of patients ${ }^{278}$. Thus, anxiety states can lead to depression states both clinically and in animal models, and molecular and physiological pathways that provide transition between these phenotypes may be promising, yet to be identified, drug targets for future therapeutic interventions.

Another major problem that must be resolved is the apparent lack of coherent long-term goals of animal and human disease modeling and CNS drug discovery. For example, the ultimate goal of animal tests is to find the most effective therapeutic treatment, without major focus on its side effects. In contrast, human tests focus on drug safety much more then on drug efficacy. Like cats misread dog behaviors, such conceptual differences in models' goals produce a welldocumented low yield of CNS drug discovery ${ }^{279}$, which not only stifles innovation in this field ${ }^{280}$, but also begins to impact the field in the long-run, as many pharmaceutical giants continue to shut down their CNS drug discovery programs, and refocus on other, non-psychiatric diseases ${ }^{281}$. The solution to this problem would be a better synchronization of research goals at pre- and clinical stages, for example, by including a drug safety component into preclinical drug discovery testing and by focusing more on drug efficacy during pilot clinical studies, with subsequent additional trials aimed at reducing drug side effects by testing safer analogs, metabolites or other derivatives once the high efficacy of the prototypic drug was established in both pre- and clinical trials. Thus, instead of proclaiming a novel promising drug a clinical failure due to its side-effects, a wiser strategy would be to screen for its safer compounds first, before making a final determination. Thus, the field of antidepressant drug screening can be reinvigorated and innovated, rather than suffer a gradual decline and decay. 
Finally, we want to emphasize that, despite some limitations and complications that animal modeling and drug screening in biological psychiatry are facing, the field should not be left behind by clinical research. Animal models represent a valuable tool to assess deeply and maximally the neurobiological and genetic determinants of disorders. Thus, further innovation of biological methodology can complement recent clinical findings, and may soon lead to new comprehensive biomedical theories of depression.

\section{Acknowledgments}

This research was supported by the Russian Foundation for Basic Research grant 16-0400851 to AVK. KAD is supported by the RFBR grant 18-34-00996. AVK is the Chair of the International Zebrafish Neuroscience Research Consortium (ZNRC) and the President of the International Stress and Behavior Society (ISBS, www.stress-and-behavior.com), chairing the ISBS Special Panel on experimental and translational depression models that coordinated this multi-lab study. The authors have no other roles or financial involvement with any organization or entity with a financial interest in, or financial conflict with, the subject matter or materials discussed in the manuscript apart from those disclosed. 
Figure 1. Bar chart representing frequency of common comorbid conditions with major depression ${ }^{14}$.

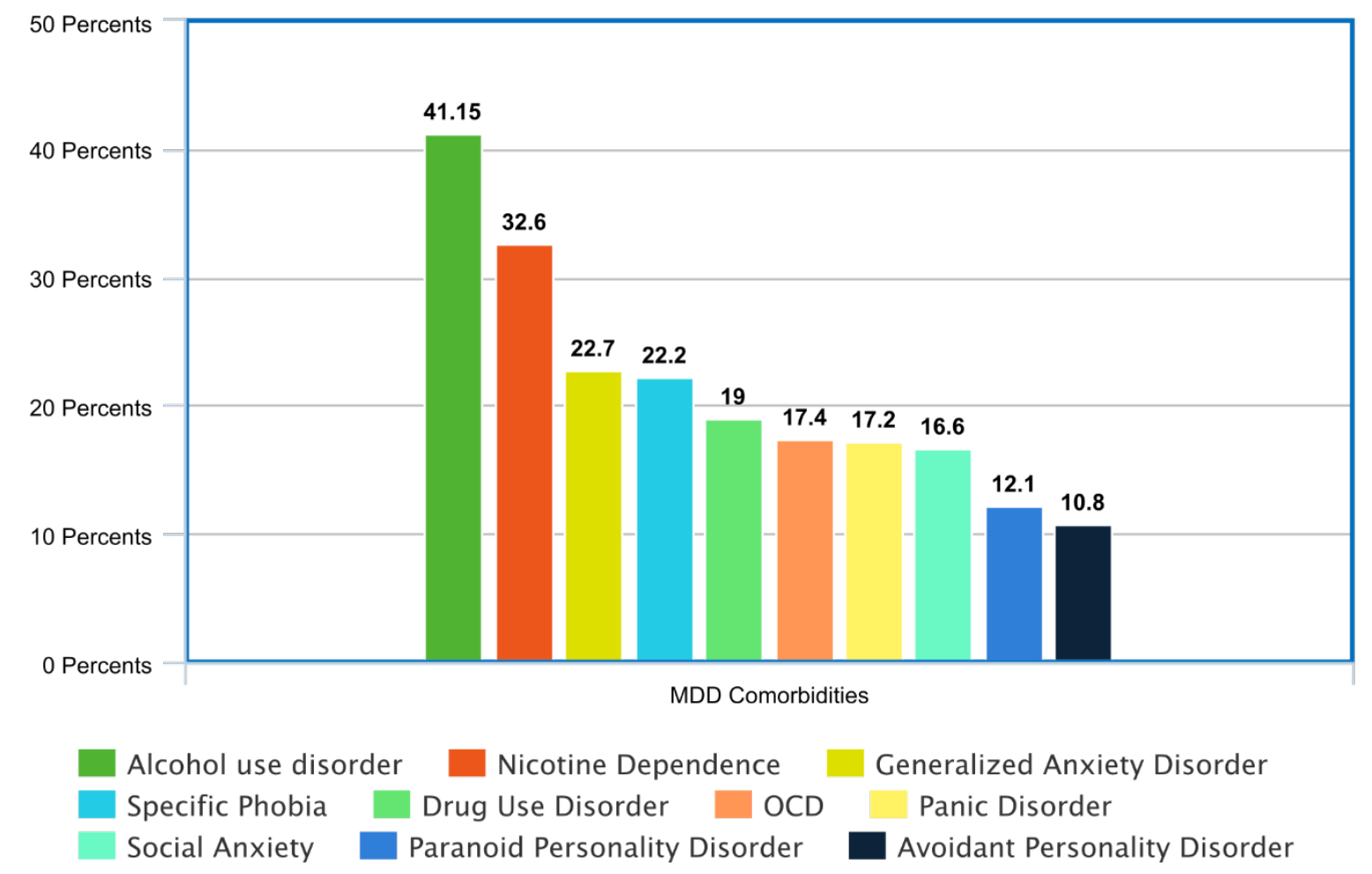


Figure 2. Use of animal models of depression for 2003-2018, Pubmed searches [species] models of depression. In case of fishes, zebrafish, Carassius auratus, goldfish, Poecilia, Oryzias, Acipenser, salmon were used. In case of non-human primates, bonobos, chimpanzee and macaques were used. (A) Cumulative number of articles per year - can be clearly seen superiority of rodents' models in translational depression research. (B) Relative number of articles per year - was calculated as year $n$ to year 2003 ratio in given category and expressed as percent. Can be seen faster relative growth of fish models that are novel for depression research.

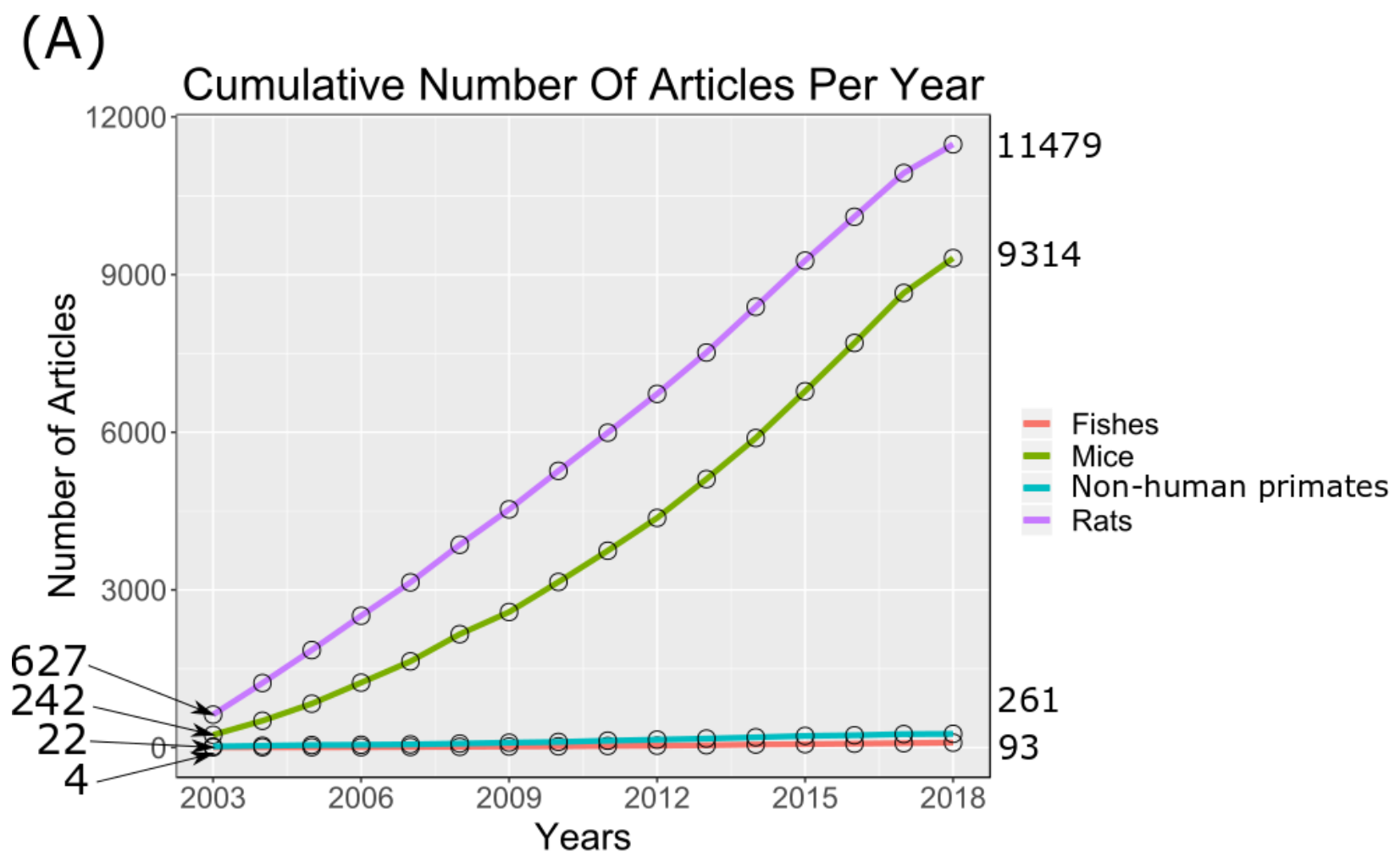

(B) Relative Number Of Articles Per Year

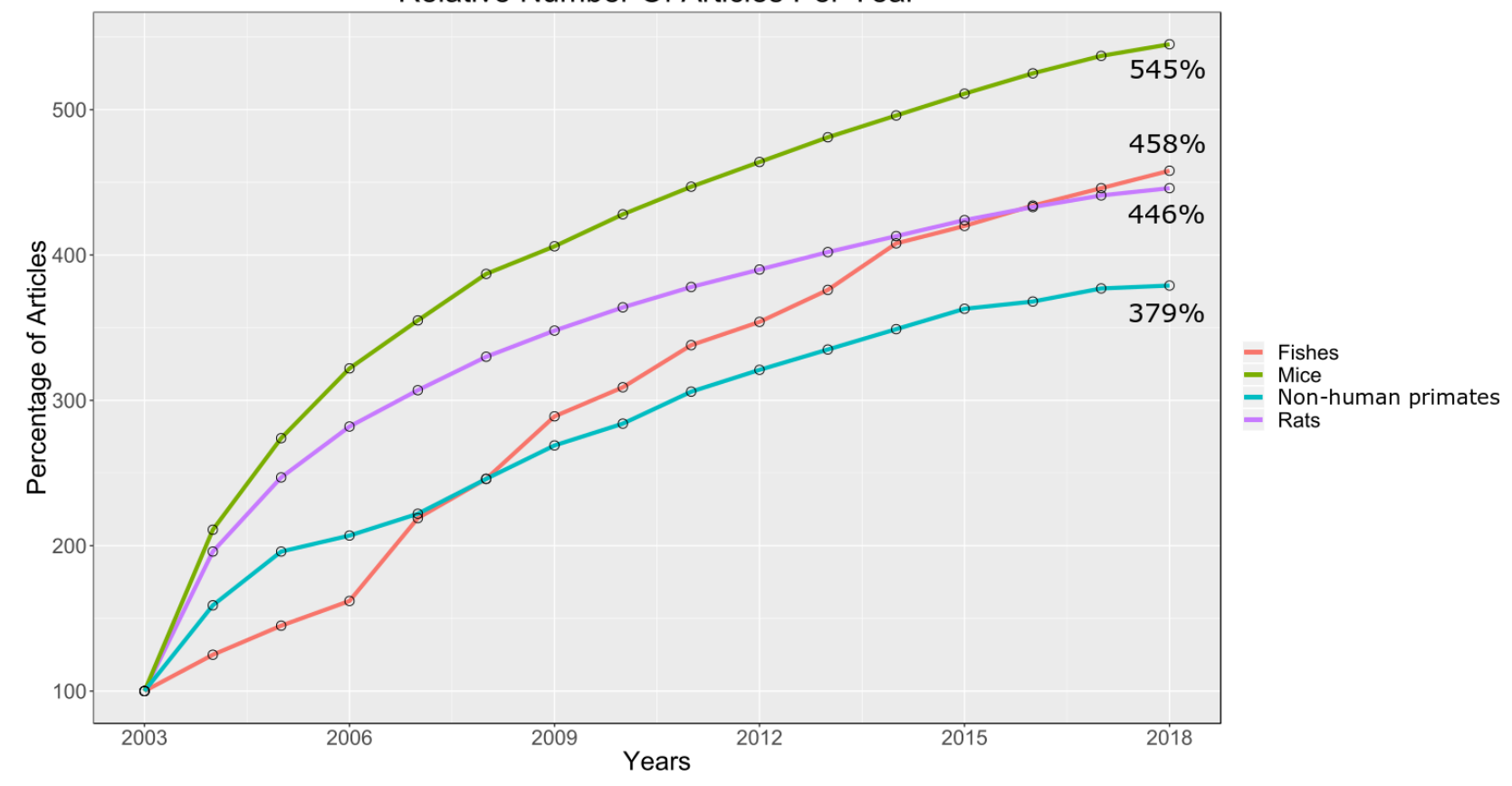


Table 1. Example of major depression neuropathological subtypes that can be identified ${ }^{2}$. Levels of severity were given depending on most frequent HAMD unit, where 0 - is minimal, for anergia, fatigue, insomnias -2 is maximum, and for anxiety, anhedonia and psychomotor retardation 4 is maximum².

\begin{tabular}{|l|c|c|c|c|}
\hline Symptom Severity & Biotype 1 & Biotype 2 & Biotype 3 & Biotype 4 \\
\hline Anhedonia & Moderate & Moderate & Severe & Severe \\
\hline Psychomotor retardation & Mild & Mild & Mild & Mild \\
\hline Anxiety & Moderate & Mild & Mild & Moderate \\
\hline Early Insomnia & Severe & Mild & Severe & Severe \\
\hline Middle Insomnia & Severe & Mild & Moderate & Severe \\
\hline Anergia, Fatigue & Severe & Severe & Moderate & Moderate \\
\hline
\end{tabular}


Table 2. Selected examples of rodents' experimental models of major depression addressing distinct aspects of affective pathogenesis.

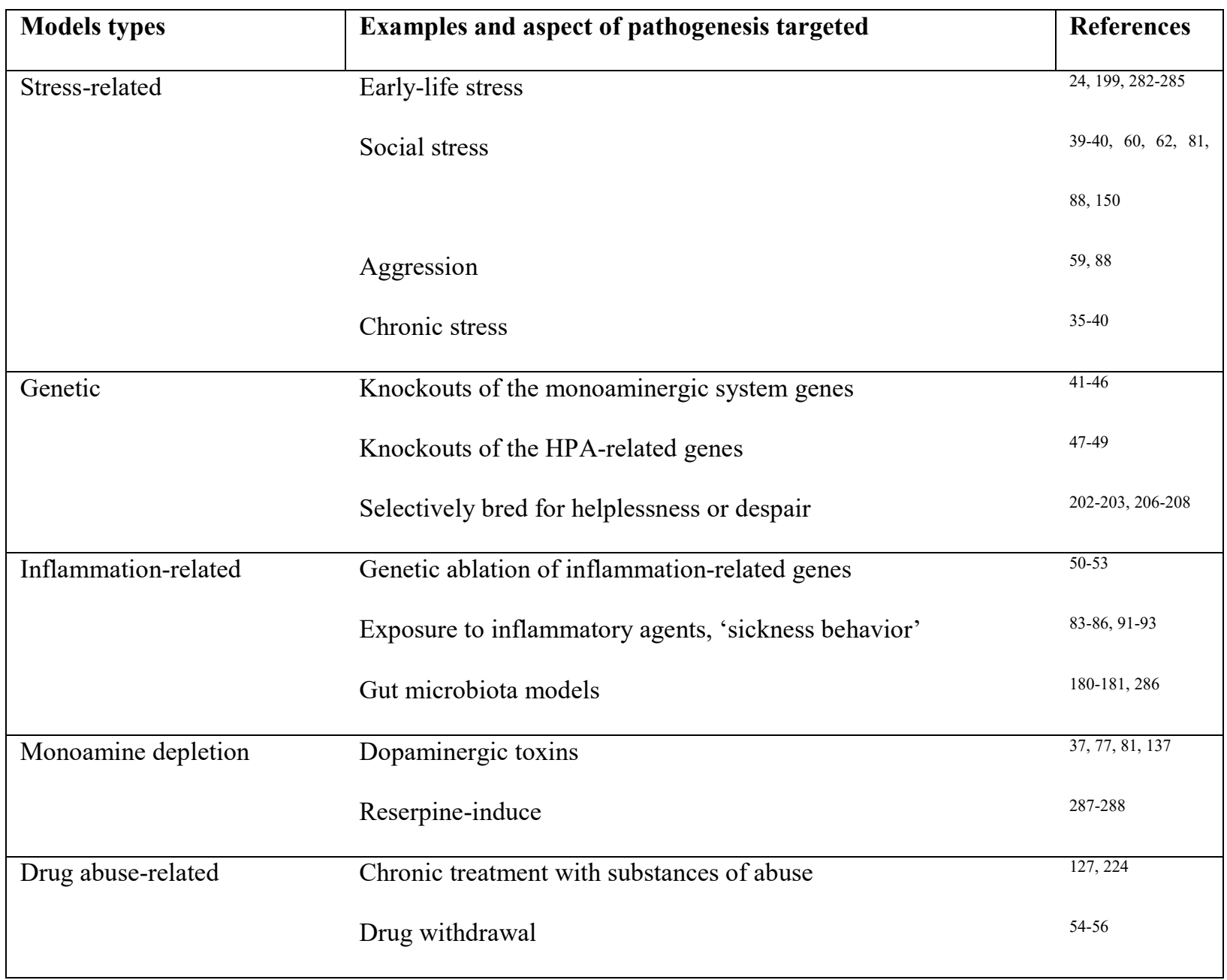

HPA - hypothalamic-pituitary-adrenal axis 
Table 3. Selected non-rodent models for studying neurobiological conditions

\begin{tabular}{|c|c|c|}
\hline Model & Non-human primates & Fish \\
\hline Stress-induced & $\begin{array}{l}\text { Chronic stress induced affective disruptions }{ }^{140} \text {, } \\
\text { especially effective are social stress models, } \\
\text { such as separation }^{122-127}\end{array}$ & $\begin{array}{l}\text { Acute }^{289} \text { or chronic } \text { stress }^{148-149,151,290} \text { exposure, } \\
\text { including social stress } \\
\text { and disrupted HPA axis }{ }^{148-149,151,289-290} \text { (sensitive to } \\
\text { antidepressant treatments }{ }^{151} \text { ) }\end{array}$ \\
\hline Pharmacological & $\begin{array}{l}\text { G-methyl-p-tyrosine or reserpine may reduce } \\
\text { social interactions and locomotion, as well as } \\
\text { induce anhedonia-like lack of environmental } \\
\text { interaction }^{126,131}\end{array}$ & $\begin{array}{l}\text { Repeated intake of psychostimulants provokes behavioral } \\
\text { sensitization }{ }^{292} \text {. Chronic exposure to reserpine }{ }^{293} \text {, } \\
\text { rotenone }^{294} \text { or } \mathrm{SiO}_{2} \text { nanoparticles }{ }^{295} \text { evokes depression- } \\
\text { like behaviors }\end{array}$ \\
\hline Genetic & $\begin{array}{l}\text { Interactions between the serotonin transporter } \\
\text { gene-linked polymorphic region (5-HTTLPR) } \\
\text { polymorphisms and rearing type have been } \\
\text { linked to different behaviors associated with } \\
\text { stress }^{121}\end{array}$ & $\begin{array}{l}\text { Knockout of the GR gene causes elevation of whole-body } \\
\text { cortisol levels and changes exploration and habituation } \\
\text { behavior }^{296-297}\end{array}$ \\
\hline
\end{tabular}

HPA - hypothalamic-pituitary-adrenal axis 


\section{References}

1. Organization, W. H., Depression and other common mental disorders: global health estimates. 2017.

2. Drysdale, A. T.; Grosenick, L.; Downar, J.; Dunlop, K.; Mansouri, F.; Meng, Y.; Fetcho, R. N.; Zebley, B.; Oathes, D. J.; Etkin, A.; Schatzberg, A. F.; Sudheimer, K.; Keller, J.; Mayberg, H. S.; Gunning, F. M.; Alexopoulos, G. S.; Fox, M. D.; Pascual-Leone, A.; Voss, H. U.; Casey, B. J.; Dubin, M. J.; Liston, C., Resting-state connectivity biomarkers define neurophysiological subtypes of depression. Nat Med 2017, 23 (1), 28-38.

3. Insel, T. R.; Cuthbert, B. N., Medicine. Brain disorders? Precisely. Science 2015, 348 (6234), 499-500.

4. Nestler, E. J.; Hyman, S. E., Animal models of neuropsychiatric disorders. Nat Neurosci 2010, 13 (10), 1161-9.

5. Duman, R. S.; Aghajanian, G. K.; Sanacora, G.; Krystal, J. H., Synaptic plasticity and depression: new insights from stress and rapid-acting antidepressants. Nat Med 2016, 22 (3), 23849.

6. Tokuda, T.; Yoshimoto, J.; Shimizu, Y.; Okada, G.; Takamura, M.; Okamoto, Y.; Yamawaki, S.; Doya, K., Identification of depression subtypes and relevant brain regions using a data-driven approach. Scientific reports 2018, 8 (1), 14082.

7. de Vos, S.; Wardenaar, K. J.; Bos, E. H.; Wit, E. C.; de Jonge, P., Decomposing the heterogeneity of depression at the person-, symptom-, and time-level: latent variable models versus multimode principal component analysis. BMC Medical Research Methodology 2015, 15 $(1), 88$.

8. van Loo, H. M.; de Jonge, P.; Romeijn, J.-W.; Kessler, R. C.; Schoevers, R. A., Data-driven subtypes of major depressive disorder: a systematic review. BMC Medicine 2012, 10 (1), 156.

9. Rush, A. J.; Trivedi, M. H.; Wisniewski, S. R.; Nierenberg, A. A.; Stewart, J. W.; Warden, D.; Niederehe, G.; Thase, M. E.; Lavori, P. W.; Lebowitz, B. D.; McGrath, P. J.; Rosenbaum, J. F.; Sackeim, H. A.; Kupfer, D. J.; Luther, J.; Fava, M., Acute and longer-term outcomes in depressed outpatients requiring one or several treatment steps: a STAR*D report. Am J Psychiatry 2006, 163 (11), 1905-17.

10. Cryan, J. F.; Mombereau, C., In search of a depressed mouse: utility of models for studying depression-related behavior in genetically modified mice. Mol Psychiatry 2004, 9 (4), 326-57.

11. Huynh, N. N.; McIntyre, R. S., What Are the Implications of the STAR*D Trial for Primary Care? A Review and Synthesis. Prim Care Companion J Clin Psychiatry 2008, 10 (2), 91-6.

12. Insel, T. R.; Charney, D. S., Research on major depression: strategies and priorities. JAMA 2003, 289 (23), 3167-8.

13. Wong, M. L.; Licinio, J., From monoamines to genomic targets: a paradigm shift for drug discovery in depression. Nat Rev Drug Discov 2004, 3 (2), 136-51.

14. Blanco, C.; Okuda, M.; Markowitz, J. C.; Liu, S.-M.; Grant, B. F.; Hasin, D. S., The Epidemiology of Chronic Major Depressive Disorder and Dysthymic Disorder: Results from the National Epidemiologic Survey on Alcohol and Related Conditions. The Journal of clinical psychiatry 2010, 71 (12), 1645-1656.

15. Zahn-Waxler, C.; Klimes-Dougan, B.; Slattery, M. J., Internalizing problems of childhood and adolescence: Prospects, pitfalls, and progress in understanding the development of anxiety and depression. Development and psychopathology 2000, 12 (3), 443-466.

16. Czeh, B.; Fuchs, E.; Wiborg, O.; Simon, M., Animal models of major depression and their clinical implications. Prog Neuropsychopharmacol Biol Psychiatry 2016, 64, 293-310.

17. Schildkraut, J. J., The catecholamine hypothesis of affective disorders: a review of supporting evidence. American journal of Psychiatry 1965, 122 (5), 509-522.

18. Lapin, I.; Oxenkrug, G., Intensification of the central serotoninergic processes as a possible determinant of the thymoleptic effect. The Lancet 1969, 293 (7586), 132-136.

19. Miller, A. H.; Raison, C. L., The role of inflammation in depression: from evolutionary imperative to modern treatment target. Nature Reviews Immunology 2016, 16 (1), 22. 
20. Slavich, G. M.; Irwin, M. R., From stress to inflammation and major depressive disorder: a social signal transduction theory of depression. Psychol Bull 2014, 140 (3), 774-815.

21. Felger, J. C.; Lotrich, F. E., Inflammatory cytokines in depression: neurobiological mechanisms and therapeutic implications. Neuroscience 2013, 246, 199-229.

22. Insel, T. R.; Voon, V.; Nye, J. S.; Brown, V. J.; Altevogt, B. M.; Bullmore, E. T.; Goodwin, G. M.; Howard, R. J.; Kupfer, D. J.; Malloch, G.; Marston, H. M.; Nutt, D. J.; Robbins, T. W.; Stahl, S. M.; Tricklebank, M. D.; Williams, J. H.; Sahakian, B. J., Innovative solutions to novel drug development in mental health. Neurosci Biobehav Rev 2013, 37 (10 Pt 1), 2438-44.

23. Ma, L.; Demin, K. A.; Kolesnikova, T. O.; Kharsko, S. L.; Zhu, X.; Yuan, X.; Song, C.; Meshalkina, D. A.; Leonard, B. E.; Tian, L.; Kalueff, A. V., Animal inflammation-based models of depression and their application to drug discovery. Expert Opin Drug Discov 2017, 12 (10), 995-1009.

24. Schmidt, M. V.; Wang, X. D.; Meijer, O. C., Early life stress paradigms in rodents: potential animal models of depression? Psychopharmacology (Berl) 2011, 214 (1), 131-40.

25. Willner, P., Behavioural models in psychopharmacology: theoretical, industrial and clinical perspectives. Cambridge University Press: 1991.

26. Willner, P.; Mitchell, P. J., The validity of animal models of predisposition to depression. Behav Pharmacol 2002, 13 (3), 169-88.

27. Anisman, H.; Matheson, K., Stress, depression, and anhedonia: caveats concerning animal models. Neurosci Biobehav Rev 2005, 29 (4-5), 525-46.

28. Bechtholt, A. J.; Lucki, I., Effects of Serotonin-Related Gene Deletion on Measures of Anxiety, Depression, and Neurotransmission. In The Serotonin Receptors: From Molecular Pharmacology to Human Therapeutics, Roth, B. L., Ed. Humana Press: Totowa, NJ, 2006; pp 577-606.

29. Mohammad, F.; Ho, J.; Woo, J. H.; Lim, C. L.; Poon, D. J.; Lamba, B.; Claridge-Chang, A., Concordance and incongruence in preclinical anxiety models: Systematic review and metaanalyses. Neurosci Biobehav Rev 2016, 68, 504-29.

30. Kreiner, G.; Chmielarz, P.; Roman, A.; Nalepa, I., Gender differences in genetic mouse models evaluated for depressive-like and antidepressant behavior. Pharmacol Rep 2013, 65 (6), $1580-90$.

31. Dantzer, R.; O'Connor, J. C.; Freund, G. G.; Johnson, R. W.; Kelley, K. W., From inflammation to sickness and depression: when the immune system subjugates the brain. Nat Rev Neurosci 2008, 9 (1), 46-56.

32. Kane, M. J.; Angoa-Perez, M.; Briggs, D. I.; Sykes, C. E.; Francescutti, D. M.; Rosenberg, D. R.; Kuhn, D. M., Mice genetically depleted of brain serotonin display social impairments, communication deficits and repetitive behaviors: possible relevance to autism. PLoS One 2012, 7 (11), e48975.

33. Angoa-Perez, M.; Kane, M. J.; Briggs, D. I.; Sykes, C. E.; Shah, M. M.; Francescutti, D. M.; Rosenberg, D. R.; Thomas, D. M.; Kuhn, D. M., Genetic depletion of brain 5HT reveals a common molecular pathway mediating compulsivity and impulsivity. J Neurochem 2012, 121 (6), 974-84.

34. Angoa-Perez, M.; Kane, M. J.; Briggs, D. I.; Herrera-Mundo, N.; Sykes, C. E.; Francescutti, D. M.; Kuhn, D. M., Mice genetically depleted of brain serotonin do not display a depression-like behavioral phenotype. ACS Chemical Neuroscience 2014, 5 (10), 908-19.

35. Elizalde, N.; Gil-Bea, F. J.; Ramirez, M. J.; Aisa, B.; Lasheras, B.; Del Rio, J.; Tordera, R. M., Long-lasting behavioral effects and recognition memory deficit induced by chronic mild stress in mice: effect of antidepressant treatment. Psychopharmacology (Berl) 2008, 199 (1), 1-14.

36. Bhutani, M. K.; Bishnoi, M.; Kulkarni, S. K., Anti-depressant like effect of curcumin and its combination with piperine in unpredictable chronic stress-induced behavioral, biochemical and neurochemical changes. Pharmacol Biochem Behav 2009, 92 (1), 39-43.

37. Shi, C. G.; Wang, L. M.; Wu, Y.; Wang, P.; Gan, Z. J.; Lin, K.; Jiang, L. X.; Xu, Z. Q.; Fan, M., Intranasal administration of nerve growth factor produces antidepressant-like effects in animals. Neurochem Res 2010, 35 (9), 1302-14. 
38. Filho, C. B.; Jesse, C. R.; Donato, F.; Giacomeli, R.; Del Fabbro, L.; da Silva Antunes, M.; de Gomes, M. G.; Goes, A. T.; Boeira, S. P.; Prigol, M.; Souza, L. C., Chronic unpredictable mild stress decreases BDNF and NGF levels and $\mathrm{Na}(+), \mathrm{K}(+)$-ATPase activity in the hippocampus and prefrontal cortex of mice: antidepressant effect of chrysin. Neuroscience 2015, 289, 367-80.

39. Krishnan, V.; Han, M. H.; Graham, D. L.; Berton, O.; Renthal, W.; Russo, S. J.; Laplant, Q.; Graham, A.; Lutter, M.; Lagace, D. C.; Ghose, S.; Reister, R.; Tannous, P.; Green, T. A.; Neve, R. L.; Chakravarty, S.; Kumar, A.; Eisch, A. J.; Self, D. W.; Lee, F. S.; Tamminga, C. A.; Cooper, D. C.; Gershenfeld, H. K.; Nestler, E. J., Molecular adaptations underlying susceptibility and resistance to social defeat in brain reward regions. Cell 2007, 131 (2), 391-404.

40. Golden, S. A.; Covington, H. E., 3rd; Berton, O.; Russo, S. J., A standardized protocol for repeated social defeat stress in mice. Nat Protoc 2011, 6 (8), 1183-91.

41. Lira, A.; Zhou, M.; Castanon, N.; Ansorge, M. S.; Gordon, J. A.; Francis, J. H.; BradleyMoore, M.; Lira, J.; Underwood, M. D.; Arango, V.; Kung, H. F.; Hofer, M. A.; Hen, R.; Gingrich, J. A., Altered depression-related behaviors and functional changes in the dorsal raphe nucleus of serotonin transporter-deficient mice. Biol Psychiatry 2003, 54 (10), 960-71.

42. Holmes, A.; Yang, R. J.; Murphy, D. L.; Crawley, J. N., Evaluation of antidepressantrelated behavioral responses in mice lacking the serotonin transporter. Neuropsychopharmacology 2002, 27 (6), 914-23.

43. Kalueff, A. V.; Olivier, J. D.; Nonkes, L. J.; Homberg, J. R., Conserved role for the serotonin transporter gene in rat and mouse neurobehavioral endophenotypes. Neurosci Biobehav Rev 2010, 34 (3), 373-86.

44. Perona, M. T.; Waters, S.; Hall, F. S.; Sora, I.; Lesch, K. P.; Murphy, D. L.; Caron, M.; Uhl, G. R., Animal models of depression in dopamine, serotonin, and norepinephrine transporter knockout mice: prominent effects of dopamine transporter deletions. Behav Pharmacol 2008, 19 (5-6), 566-74.

45. Lahdesmaki, J.; Sallinen, J.; MacDonald, E.; Kobilka, B. K.; Fagerholm, V.; Scheinin, M., Behavioral and neurochemical characterization of alpha(2A)-adrenergic receptor knockout mice. Neuroscience 2002, 113 (2), 289-99.

46. Schramm, N. L.; McDonald, M. P.; Limbird, L. E., The alpha(2a)-adrenergic receptor plays a protective role in mouse behavioral models of depression and anxiety. J Neurosci 2001, 21 (13), 4875-82.

47. Muller, M. B.; Holsboer, F., Mice with mutations in the HPA-system as models for symptoms of depression. Biol Psychiatry 2006, 59 (12), 1104-15.

48. Oitzl, M. S.; de Kloet, E. R.; Joels, M.; Schmid, W.; Cole, T. J., Spatial learning deficits in mice with a targeted glucocorticoid receptor gene disruption. Eur J Neurosci 1997, 9 (11), 228496.

49. Ridder, S.; Chourbaji, S.; Hellweg, R.; Urani, A.; Zacher, C.; Schmid, W.; Zink, M.; Hortnagl, H.; Flor, H.; Henn, F. A.; Schutz, G.; Gass, P., Mice with genetically altered glucocorticoid receptor expression show altered sensitivity for stress-induced depressive reactions. J Neurosci 2005, 25 (26), 6243-50.

50. Yamada, K.; Iida, R.; Miyamoto, Y.; Saito, K.; Sekikawa, K.; Seishima, M.; Nabeshima, T., Neurobehavioral alterations in mice with a targeted deletion of the tumor necrosis factor-alpha gene: implications for emotional behavior. J Neuroimmunol 2000, 111 (1-2), 131-8.

51. Mesquita, A. R.; Correia-Neves, M.; Roque, S.; Castro, A. G.; Vieira, P.; Pedrosa, J.; Palha, J. A.; Sousa, N., IL-10 modulates depressive-like behavior. J Psychiatr Res 2008, 43 (2), 89-97.

52. Toth, L. A.; Opp, M. R., Cytokine- and microbially induced sleep responses of interleukin10 deficient mice. Am J Physiol Regul Integr Comp Physiol 2001, 280 (6), R1806-14.

53. Smith, E. M.; Cadet, P.; Stefano, G. B.; Opp, M. R.; Hughes, T. K., Jr., IL-10 as a mediator in the HPA axis and brain. J Neuroimmunol 1999, 100 (1-2), 140-8.

54. Harrison, A. A.; Liem, Y. T.; Markou, A., Fluoxetine combined with a serotonin-1A receptor antagonist reversed reward deficits observed during nicotine and amphetamine withdrawal in rats. Neuropsychopharmacology 2001, 25 (1), 55-71. 
55. Paterson, N. E.; Myers, C.; Markou, A., Effects of repeated withdrawal from continuous amphetamine administration on brain reward function in rats. Psychopharmacology (Berl) 2000, $152(4), 440-6$.

56. Cryan, J. F.; Hoyer, D.; Markou, A., Withdrawal from chronic amphetamine induces depressive-like behavioral effects in rodents. Biol Psychiatry 2003, 54 (1), 49-58.

57. Hodes, G. E.; Kana, V.; Menard, C.; Merad, M.; Russo, S. J., Neuroimmune mechanisms of depression. Nat Neurosci 2015, 18 (10), 1386-93.

58. Keifer, J.; Summers, C. H., Putting the "Biology" Back into "Neurobiology": The Strength of Diversity in Animal Model Systems for Neuroscience Research. Front Syst Neurosci 2016, 10, 69.

59. Kudryavtseva, N. N.; Bondar, N. P.; Avgustinovich, D. F., Effects of repeated experience of aggression on the aggressive motivation and development of anxiety in male mice. Neurosci Behav Physiol 2004, 34 (7), 721-30.

60. Martin, A. L.; Brown, R. E., The lonely mouse: verification of a separation-induced model of depression in female mice. Behav Brain Res 2010, 207 (1), 196-207.

61. Takatsu-Coleman, A. L.; Patti, C. L.; Zanin, K. A.; Zager, A.; Carvalho, R. C.; Borcoi, A. R.; Ceccon, L. M.; Berro, L. F.; Tufik, S.; Andersen, M. L.; Frussa-Filho, R., Short-term social isolation induces depressive-like behaviour and reinstates the retrieval of an aversive task: moodcongruent memory in male mice? J Psychiatry Neurosci 2013, 38 (4), 259-68.

62. Liu, X.; Wu, R.; Tai, F.; Ma, L.; Wei, B.; Yang, X.; Zhang, X.; Jia, R., Effects of group housing on stress induced emotional and neuroendocrine alterations. Brain Res 2013, 1502, 7180 .

63. Liberzon, I.; Krstov, M.; Young, E. A., Stress-restress: effects on ACTH and fast feedback. Psychoneuroendocrinology 1997, 22 (6), 443-53.

64. Serova, L. I.; Laukova, M.; Alaluf, L. G.; Pucillo, L.; Sabban, E. L., Intranasal neuropeptide $\mathrm{Y}$ reverses anxiety and depressive-like behavior impaired by single prolonged stress PTSD model. Eur Neuropsychopharmacol 2014, 24 (1), 142-7.

65. Belzung, C.; Lemoine, M., Criteria of validity for animal models of psychiatric disorders: focus on anxiety disorders and depression. Biol Mood Anxiety Disord 2011, 1 (1), 9.

66. Sullivan, P. F.; Neale, M. C.; Kendler, K. S., Genetic epidemiology of major depression: review and meta-analysis. Am J Psychiatry 2000, 157 (10), 1552-62.

67. Bosker, F. J.; Hartman, C. A.; Nolte, I. M.; Prins, B. P.; Terpstra, P.; Posthuma, D.; van Veen, T.; Willemsen, G.; DeRijk, R. H.; de Geus, E. J.; Hoogendijk, W. J.; Sullivan, P. F.; Penninx, B. W.; Boomsma, D. I.; Snieder, H.; Nolen, W. A., Poor replication of candidate genes for major depressive disorder using genome-wide association data. Mol Psychiatry 2011, 16 (5), 516-32.

68. Network; Pathway Analysis Subgroup of Psychiatric Genomics, C., Psychiatric genomewide association study analyses implicate neuronal, immune and histone pathways. Nat Neurosci 2015, 18 (2), 199-209.

69. Sallinen, J.; Haapalinna, A.; MacDonald, E.; Viitamaa, T.; Lahdesmaki, J.; Rybnikova, E.; Pelto-Huikko, M.; Kobilka, B. K.; Scheinin, M., Genetic alteration of the alpha2-adrenoceptor subtype $\mathrm{c}$ in mice affects the development of behavioral despair and stress-induced increases in plasma corticosterone levels. Mol Psychiatry 1999, 4 (5), 443-52.

70. Bjorklund, M.; Sirvio, J.; Puolivali, J.; Sallinen, J.; Jakala, P.; Scheinin, M.; Kobilka, B. K.; Riekkinen, P., Jr., Alpha2C-adrenoceptor-overexpressing mice are impaired in executing nonspatial and spatial escape strategies. Mol Pharmacol 1998, 54 (3), 569-76.

71. Spielewoy, C.; Roubert, C.; Hamon, M.; Nosten, M.; Betancur, C.; Giros, B., Behavioural disturbances associated with hyperdopaminergia in dopamine-transporter knockout mice. Behavioural Pharmacology 2000, 11 (3-4), 279-290.

72. Holmes, A.; Hollon, T. R.; Gleason, T. C.; Liu, Z.; Dreiling, J.; Sibley, D. R.; Crawley, J. $\mathrm{N}$., Behavioral characterization of dopamine D5 receptor null mutant mice. Behav Neurosci 2001, 115 (5), 1129-44.

73. Filliol, D.; Ghozland, S.; Chluba, J.; Martin, M.; Matthes, H. W.; Simonin, F.; Befort, K.; Gaveriaux-Ruff, C.; Dierich, A.; LeMeur, M.; Valverde, O.; Maldonado, R.; Kieffer, B. L., Mice 
deficient for delta- and mu-opioid receptors exhibit opposing alterations of emotional responses. Nat Genet 2000, 25 (2), 195-200.

74. Ide, S.; Sora, I.; Ikeda, K.; Minami, M.; Uhl, G. R.; Ishihara, K., Reduced emotional and corticosterone responses to stress in mu-opioid receptor knockout mice. Neuropharmacology 2010, 58 (1), 241-7.

75. Walls, A. B.; Eyjolfsson, E. M.; Smeland, O. B.; Nilsen, L. H.; Schousboe, I.; Schousboe, A.; Sonnewald, U.; Waagepetersen, H. S., Knockout of GAD65 has major impact on synaptic GABA synthesized from astrocyte-derived glutamine. J Cereb Blood Flow Metab 2011, 31 (2), 494-503.

76. Stork, O.; Ji, F. Y.; Kaneko, K.; Stork, S.; Yoshinobu, Y.; Moriya, T.; Shibata, S.; Obata, K., Postnatal development of a GABA deficit and disturbance of neural functions in mice lacking GAD65. Brain Res 2000, 865 (1), 45-58.

77. Miyamoto, Y.; Yamada, K.; Noda, Y.; Mori, H.; Mishina, M.; Nabeshima, T., Lower sensitivity to stress and altered monoaminergic neuronal function in mice lacking the NMDA receptor epsilon 4 subunit. J Neurosci 2002, 22 (6), 2335-42.

78. Cryan, J. F.; Kelly, P. H.; Neijt, H. C.; Sansig, G.; Flor, P. J.; van Der Putten, H., Antidepressant and anxiolytic-like effects in mice lacking the group III metabotropic glutamate receptor mGluR7. Eur J Neurosci 2003, 17 (11), 2409-17.

79. Tordera, R. M.; Totterdell, S.; Wojcik, S. M.; Brose, N.; Elizalde, N.; Lasheras, B.; Del Rio, J., Enhanced anxiety, depressive-like behaviour and impaired recognition memory in mice with reduced expression of the vesicular glutamate transporter 1 (VGLUT1). Eur J Neurosci 2007, 25 (1), 281-90.

80. Garcia-Garcia, A. L.; Elizalde, N.; Matrov, D.; Harro, J.; Wojcik, S. M.; Venzala, E.; Ramirez, M. J.; Del Rio, J.; Tordera, R. M., Increased vulnerability to depressive-like behavior of mice with decreased expression of VGLUT1. Biol Psychiatry 2009, 66 (3), 275-82.

81. Caspi, A.; Sugden, K.; Moffitt, T. E.; Taylor, A.; Craig, I. W.; Harrington, H.; McClay, J.; Mill, J.; Martin, J.; Braithwaite, A.; Poulton, R., Influence of life stress on depression: moderation by a polymorphism in the 5-HTT gene. Science 2003, 301 (5631), 386-9.

82. Risch, N.; Herrell, R.; Lehner, T.; Liang, K.-Y.; Eaves, L.; Hoh, J.; Griem, A.; Kovacs, M.; Ott, J.; Merikangas, K. R., Interaction between the serotonin transporter gene (5-HTTLPR), stressful life events, and risk of depression: a meta-analysis. Jama 2009, 301 (23), 2462-2471.

83. Loftis, J. M.; Huckans, M.; Morasco, B. J., Neuroimmune mechanisms of cytokine-induced depression: current theories and novel treatment strategies. Neurobiol Dis 2010, 37 (3), 519-33.

84. Remus, J. L.; Dantzer, R., Inflammation Models of Depression in Rodents: Relevance to Psychotropic Drug Discovery. Int J Neuropsychopharmacol 2016, 19 (9).

85. Salazar, A.; Gonzalez-Rivera, B. L.; Redus, L.; Parrott, J. M.; O'Connor, J. C., Indoleamine 2,3-dioxygenase mediates anhedonia and anxiety-like behaviors caused by peripheral lipopolysaccharide immune challenge. Horm Behav 2012, 62 (3), 202-9.

86. Biesmans, S.; Matthews, L. J.; Bouwknecht, J. A.; De Haes, P.; Hellings, N.; Meert, T. F.; Nuydens, R.; Ver Donck, L., Systematic Analysis of the Cytokine and Anhedonia Response to Peripheral Lipopolysaccharide Administration in Rats. Biomed Res Int 2016, 2016, 9085273.

87. Walker, F. R.; Knott, B.; Hodgson, D. M., Neonatal endotoxin exposure modifies the acoustic startle response and circulating levels of corticosterone in the adult rat but only following acute stress. J Psychiatr Res 2008, 42 (13), 1094-103.

88. Granger, D. A.; Hood, K. E.; Dreschel, N. A.; Sergeant, E.; Likos, A., Developmental effects of early immune stress on aggressive, socially reactive, and inhibited behaviors. Dev Psychopathol 2001, 13 (3), 599-610.

89. Majidi, J.; Kosari-Nasab, M.; Salari, A. A., Developmental minocycline treatment reverses the effects of neonatal immune activation on anxiety- and depression-like behaviors, hippocampal inflammation, and HPA axis activity in adult mice. Brain Res Bull 2016, 120, 1-13.

90. Gibney, S. M.; McGuinness, B.; Prendergast, C.; Harkin, A.; Connor, T. J., Poly I:Cinduced activation of the immune response is accompanied by depression and anxiety-like behaviours, kynurenine pathway activation and reduced BDNF expression. Brain Behav Immun 2013, 28, 170-81. 
91. Kaneko, N.; Kudo, K.; Mabuchi, T.; Takemoto, K.; Fujimaki, K.; Wati, H.; Iguchi, H.; Tezuka, H.; Kanba, S., Suppression of cell proliferation by interferon-alpha through interleukin-1 production in adult rat dentate gyrus. Neuropsychopharmacology 2006, 31 (12), 2619-26.

92. Orsal, A. S.; Blois, S. M.; Bermpohl, D.; Schaefer, M.; Coquery, N., Administration of interferon-alpha in mice provokes peripheral and central modulation of immune cells, accompanied by behavioral effects. Neuropsychobiology 2008, 58 (3-4), 211-22.

93. Kentner, A. C.; James, J. S.; Miguelez, M.; Bielajew, C., Investigating the hedonic effects of interferon-alpha on female rats using brain-stimulation reward. Behav Brain Res 2007, 177 (1), 90-9.

94. Moreau, M.; Andre, C.; O'Connor, J. C.; Dumich, S. A.; Woods, J. A.; Kelley, K. W.; Dantzer, R.; Lestage, J.; Castanon, N., Inoculation of Bacillus Calmette-Guerin to mice induces an acute episode of sickness behavior followed by chronic depressive-like behavior. Brain Behav Immun 2008, 22 (7), 1087-95.

95. O'Connor, J. C.; Lawson, M. A.; Andre, C.; Briley, E. M.; Szegedi, S. S.; Lestage, J.; Castanon, N.; Herkenham, M.; Dantzer, R.; Kelley, K. W., Induction of IDO by bacille CalmetteGuerin is responsible for development of murine depressive-like behavior. J Immunol 2009, 182 (5), 3202-12.

96. Renoir, T.; Pang, T. Y.; Lanfumey, L., Drug withdrawal-induced depression: serotonergic and plasticity changes in animal models. Neurosci Biobehav Rev 2012, 36 (1), 696-726.

97. Zabegalov, K. N.; Kolesnikova, T. O.; Khatsko, S. L.; Volgin, A. D.; Yakovlev, O. A.; Amstislavskaya, T. G.; Alekseeva, P. A.; Meshalkina, D. A.; Friend, A. J.; Bao, W.; Demin, K. A.; Gainetdinov, R. R.; Kalueff, A. V., Understanding antidepressant discontinuation syndrome (ADS) through preclinical experimental models. Eur J Pharmacol 2018, 829, 129-140.

98. Güdük, M.; Erensoy, İ. Y.; Ersümer, F., Mania/hypomania associated with antidepressant discontinuation. Düşünen Adam: The Journal of Psychiatry and Neurological Sciences 2013, 26 (3), 303-306.

99. Merali, Z.; Brennan, K.; Brau, P.; Anisman, H., Dissociating anorexia and anhedonia elicited by interleukin-1beta: antidepressant and gender effects on responding for "free chow" and "earned" sucrose intake. Psychopharmacology (Berl) 2003, 165 (4), 413-8.

100. Sammut, S.; Bethus, I.; Goodall, G.; Muscat, R., Antidepressant reversal of interferonalpha-induced anhedonia. Physiol Behav 2002, 75 (5), 765-72.

101. Makino, M.; Kitano, Y.; Komiyama, C.; Hirohashi, M.; Kohno, M.; Moriyama, M.; Takasuna, K., Human interferon-alpha induces immobility in the mouse forced swimming test: involvement of the opioid system. Brain Res 2000, 852 (2), 482-4.

102. Plata-Salaman, C. R.; Oomura, Y.; Kai, Y., Tumor necrosis factor and interleukin-1 beta: suppression of food intake by direct action in the central nervous system. Brain Res 1988, 448 (1), 106-14.

103. El Yacoubi, M.; Bouali, S.; Popa, D.; Naudon, L.; Leroux-Nicollet, I.; Hamon, M.; Costentin, J.; Adrien, J.; Vaugeois, J. M., Behavioral, neurochemical, and electrophysiological characterization of a genetic mouse model of depression. Proc Natl Acad Sci U S A 2003, 100 (10), 6227-32.

104. Krueger, J. M.; Majde, J. A., Humoral links between sleep and the immune system: research issues. Ann N Y Acad Sci 2003, 992, 9-20.

105. Dantzer, R.; Bluthe, R. M.; Kelley, K. W., Androgen-dependent vasopressinergic neurotransmission attenuates interleukin-1-induced sickness behavior. Brain Res 1991, 557 (1-2), $115-20$.

106. Wood, L. J.; Nail, L. M.; Gilster, A.; Winters, K. A.; Elsea, C. R., Cancer chemotherapyrelated symptoms: evidence to suggest a role for proinflammatory cytokines. Oncol Nurs Forum 2006, 33 (3), 535-42.

107. Bonaccorso, S.; Maier, S. F.; Meltzer, H. Y.; Maes, M., Behavioral changes in rats after acute, chronic and repeated administration of interleukin-1beta: relevance for affective disorders. J Affect Disord 2003, 77 (2), 143-8. 
108. Song, C.; Horrobin, D. F.; Leonard, B. E., The comparison of changes in behavior, neurochemistry, endocrine, and immune functions after different routes, doses and durations of administrations of IL-1 beta in rats. Pharmacopsychiatry 2006, 39 (3), 88-99.

109. Nonogaki, K.; Abdallah, L.; Goulding, E. H.; Bonasera, S. J.; Tecott, L. H., Hyperactivity and reduced energy cost of physical activity in serotonin 5-HT(2C) receptor mutant mice. Diabetes 2003, 52 (2), 315-20.

110. Ballard, T. M.; Pauly-Evers, M.; Higgins, G. A.; Ouagazzal, A. M.; Mutel, V.; Borroni, E.; Kemp, J. A.; Bluethmann, H.; Kew, J. N., Severe impairment of NMDA receptor function in mice carrying targeted point mutations in the glycine binding site results in drug-resistant nonhabituating hyperactivity. $J$ Neurosci 2002, 22 (15), 6713-23.

111. Cheeta, S.; Ruigt, G.; van Proosdij, J.; Willner, P., Changes in sleep architecture following chronic mild stress. Biol Psychiatry 1997, 41 (4), 419-27.

112. Steru, L.; Chermat, R.; Thierry, B.; Simon, P., The tail suspension test: a new method for screening antidepressants in mice. Psychopharmacology (Berl) 1985, 85 (3), 367-70.

113. O'Leary, O. F.; Cryan, J. F., Towards translational rodent models of depression. Cell Tissue Res 2013, 354 (1), 141-53.

114. Porsolt, R. D.; Le Pichon, M.; Jalfre, M., Depression: a new animal model sensitive to antidepressant treatments. Nature 1977, 266 (5604), 730-2.

115. Lucki, I., The forced swimming test as a model for core and component behavioral effects of antidepressant drugs. Behav Pharmacol 1997, 8 (6-7), 523-32.

116. Porsolt, R. D.; Bertin, A.; Jalfre, M., "Behavioural despair" in rats and mice: strain differences and the effects of imipramine. Eur J Pharmacol 1978, 51 (3), 291-4.

117. Porsolt, R. D.; Bertin, A.; Jalfre, M., Behavioral despair in mice: a primary screening test for antidepressants. Arch Int Pharmacodyn Ther 1977, 229 (2), 327-36.

118. Steru, L.; Chermat, R.; Thierry, B.; Mico, J. A.; Lenegre, A.; Steru, M.; Simon, P.; Porsolt, R. D., The automated Tail Suspension Test: a computerized device which differentiates psychotropic drugs. Prog Neuropsychopharmacol Biol Psychiatry 1987, 11 (6), 659-71.

119. Commons, K. G.; Cholanians, A. B.; Babb, J. A.; Ehlinger, D. G., The Rodent Forced Swim Test Measures Stress-Coping Strategy, Not Depression-like Behavior. ACS Chem Neurosci 2017, 8 (5), 955-960.

120. Nelson, E. E.; Winslow, J. T., Non-human primates: model animals for developmental psychopathology. Neuropsychopharmacology 2009, 34 (1), 90.

121. Barr, C. S.; Newman, T. K.; Becker, M. L.; Parker, C. C.; Champoux, M.; Lesch, K.; Goldman, D.; Suomi, S.; Higley, J., The utility of the non-human primate model for studying gene by environment interactions in behavioral research. Genes, Brain and Behavior 2003, 2 (6), 336340 .

122. Suomi, S.; Harlow, H., Production and alleviation of depressive behaviors in monkeys. WH Freeman, San Francisco: 1977; Vol. 131.

123. Harro, J., Animal models of depression vulnerability. Curr Top Behav Neurosci 2013, 14, 29-54.

124. Suomi, S. J., Repetitive peer separation of young monkeys: Effects of vertical chamber confinement during separations. Journal of abnormal psychology 1973, 81 (1), 1.

125. Worlein, J. M., Nonhuman primate models of depression: effects of early experience and stress. ILAR journal 2014, 55 (2), 259-273.

126. Vellucci, S. V., Primate social behavior-anxiety or depression? Pharmacology \& therapeutics 1990, 47 (2), 167-180.

127. McKinney, W.; Moran, E.; Kramer, G., Effects of drugs on the response to social separation in rhesus monkeys. In Hormones, Drugs and Social Behavior in Primates, Spectrum Publications New York: 1983; pp 249-270.

128. Suomi, S. J.; Seaman, S. F.; Lewis, J. K.; DeLizio, R. D.; McKinney, W. T., Effects of imipramine treatment of separation-induced social disorders in rhesus monkeys. Archives of General Psychiatry 1978, 35 (3), 321-325.

129. Rasmussen, K. L.; Reite, M., Loss-induced depression in an adult macaque monkey. The American journal of psychiatry 1982. 
130. Kraemer, G. W.; Lin, D. H.; Moran, E. C.; McKinney, W. T., Effects of alcohol on the despair response to peer separation in rhesus monkeys. Psychopharmacology 1981, 73 (4), $307-$ 310.

131. Redmond, D. E.; Maas, J. W.; Kling, A.; Dekirmenjian, H., Changes in primate social behavior after treatment with alpha-methyl-para-tyrosine. Psychosomatic medicine 1971.

132. Kalidindi, A.; Kelly, S. D.; Singleton, K. S.; Guzman, D.; Merrill, L.; Willard, S. L.; Shively, C. A.; Neigh, G. N., Reduced marker of vascularization in the anterior hippocampus in a female monkey model of depression. Physiology \& behavior 2017, 172, 12-15.

133. Clarke, A. S.; Hedeker, D. R.; Ebert, M. H.; Schmidt, D. E.; McKinney, W. T.; Kraemer, G. W., Rearing experience and biogenic amine activity in infant rhesus monkeys. Biological Psychiatry 1996, 40 (5), 338-352.

134. Clarke, A. S.; Ebert, M. H.; Schmidt, D. E.; McKinney, W. T.; Kraemer, G. W., Biogenic amine activity in response to fluoxetine and desipramine in differentially reared rhesus monkeys. Biological psychiatry 1999, 46 (2), 221-228.

135. Kraemer, G. W.; Ebert, M. H.; Lake, C. R.; McKinney, W. T., Amphetamine challenge: effects in previously isolated rhesus monkeys and implications for animal models of schizophrenia. Progress in clinical and biological research 1983, 131, 199-218.

136. Kraemer, G. W.; Ebert, M. H.; Lake, C. R.; McKinney, W. T., Hypersensitivity to damphetamine several years after early social deprivation in rhesus monkeys. Psychopharmacology 1984, 82 (3), 266-271.

137. Higley, J. D.; Suomi, S. J.; Linnoila, M., A longitudinal assessment of CSF monoamine metabolite and plasma cortisol concentrations in young rhesus monkeys. Biological psychiatry 1992, 32 (2), 127-145.

138. Winslow, J. T., Neuropeptides and non-human primate social deficits associated with pathogenic rearing experience. International Journal of Developmental Neuroscience 2005, 23 (23), 245-251.

139. Kraemer, G. W.; McKinney, W. T., Interactions of pharmacological agents which alter biogenic amine metabolism and depression: An analysis of contributing factors within a primate model of depression. Journal of Affective Disorders 1979, 1 (1), 33-54.

140. Zhang, Z.-y.; Mao, Y.; Feng, X.-1.; Zheng, N.; Lü, L.-b.; Ma, Y.-y.; Qin, D.-d.; Hu, X.-t., Early adversity contributes to chronic stress induced depression-like behavior in adolescent male rhesus monkeys. Behavioural brain research 2016, 306, 154-159.

141. Felger, J. C.; Alagbe, O.; Hu, F.; Mook, D.; Freeman, A. A.; Sanchez, M. M.; Kalin, N. H.; Ratti, E.; Nemeroff, C. B.; Miller, A. H., Effects of interferon-alpha on rhesus monkeys: a nonhuman primate model of cytokine-induced depression. Biological psychiatry 2007, 62 (11), 1324-1333.

142. Meshalkina, D. A.; Kysil, E. V.; Warnick, J. E.; Demin, K. A.; Kalueff, A. V., Adult zebrafish in CNS disease modeling: a tank that's half-full, not half-empty, and still filling. $L a b$ Anim (NY) 2017, 46 (10), 378-387.

143. Demin, K. A.; Meshalkina, D. A.; Kysil, E. V.; Antonova, K. A.; Volgin, A. D.; Yakovlev, O. A.; Alekseeva, P. A.; Firuleva, M. M.; Lakstygal, A. M.; de Abreu, M. S.; Barcellos, L. J. G.; Bao, W.; Friend, A. J.; Amstislavskaya, T. G.; Rosemberg, D. B.; Musienko, P. E.; Song, C.; Kalueff, A. V., Zebrafish models relevant to studying central opioid and endocannabinoid systems. Progress in Neuro-Psychopharmacology \& Biological Psychiatry 2018.

144. Stewart, A. M.; Ullmann, J. F.; Norton, W. H.; Parker, M. O.; Brennan, C. H.; Gerlai, R.; Kalueff, A. V., Molecular psychiatry of zebrafish. Molecular Psychiatry 2015, 20 (1), 2-17.

145. Kalueff, A. V.; Stewart, A. M.; Gerlai, R., Zebrafish as an emerging model for studying complex brain disorders. Trends Pharmacol Sci 2014, 35 (2), 63-75.

146. Khan, K. M.; Collier, A. D.; Meshalkina, D. A.; Kysil, E. V.; Khatsko, S. L.; Kolesnikova, T.; Morzherin, Y. Y.; Warnick, J. E.; Kalueff, A. V.; Echevarria, D. J., Zebrafish models in neuropsychopharmacology and CNS drug discovery. Br J Pharmacol 2017, 174 (13), 1925-1944. 147. de Abreu, M. S.; Friend, A. J.; Demin, K. A.; Amstislavskaya, T. G.; Bao, W.; Kalueff, A. V., Zebrafish models: do we have valid paradigms for depression? Journal of pharmacological and toxicological methods 2018. 
148. Manuel, R.; Gorissen, M.; Zethof, J.; Ebbesson, L. O.; van de Vis, H.; Flik, G.; van den Bos, R., Unpredictable chronic stress decreases inhibitory avoidance learning in Tuebingen longfin zebrafish: stronger effects in the resting phase than in the active phase. J Exp Biol 2014, 217 (Pt 21), 3919-28.

149. Chakravarty, S.; Reddy, B. R.; Sudhakar, S. R.; Saxena, S.; Das, T.; Meghah, V.; Brahmendra Swamy, C. V.; Kumar, A.; Idris, M. M., Chronic unpredictable stress (CUS)-induced anxiety and related mood disorders in a zebrafish model: altered brain proteome profile implicates mitochondrial dysfunction. PLoS One 2013, 8 (5), e63302.

150. Fulcher, N.; Tran, S.; Shams, S.; Chatterjee, D.; Gerlai, R., Neurochemical and Behavioral Responses to Unpredictable Chronic Mild Stress Following Developmental Isolation: The Zebrafish as a Model for Major Depression. Zebrafish 2017, 14 (1), 23-34.

151. Song, C.; Liu, B. P.; Zhang, Y. P.; Peng, Z.; Wang, J.; Collier, A. D.; Echevarria, D. J.; Savelieva, K. V.; Lawrence, R. F.; Rex, C. S.; Meshalkina, D. A.; Kalueff, A. V., Modeling consequences of prolonged strong unpredictable stress in zebrafish: Complex effects on behavior and physiology. Prog Neuropsychopharmacol Biol Psychiatry 2018, 81, 384-394.

152. Pavlidis, M.; Theodoridi, A.; Tsalafouta, A., Neuroendocrine regulation of the stress response in adult zebrafish, Danio rerio. Prog Neuropsychopharmacol Biol Psychiatry 2015, 60, 121-31.

153. Zimmermann, F. F.; Altenhofen, S.; Kist, L. W.; Leite, C. E.; Bogo, M. R.; Cognato, G. P.; Bonan, C. D., Unpredictable Chronic Stress Alters Adenosine Metabolism in Zebrafish Brain. Mol Neurobiol 2016, 53 (4), 2518-28.

154. McCammon, J. M.; Sive, H., Addressing the Genetics of Human Mental Health Disorders in Model Organisms. Annu Rev Genomics Hum Genet 2015, 16, 173-97.

155. Mann, J. J., Role of the serotonergic system in the pathogenesis of major depression and suicidal behavior. Neuropsychopharmacology 1999, 21 (2), 99S-105S.

156. Rapport, M. M.; Green, A. A.; Page, I. H., Crystalline serotonin. Science 1948, 108 (2804), 329-330.

157. Popa, D.; Lena, C.; Alexandre, C.; Adrien, J., Lasting syndrome of depression produced by reduction in serotonin uptake during postnatal development: evidence from sleep, stress, and behavior. $J$ Neurosci 2008, 28 (14), 3546-54.

158. Vogel, G.; Neill, D.; Kors, D.; Hagler, M., REM sleep abnormalities in a new animal model of endogenous depression. Neurosci Biobehav Rev 1990, 14 (1), 77-83.

159. Ramboz, S.; Oosting, R.; Amara, D. A.; Kung, H. F.; Blier, P.; Mendelsohn, M.; Mann, J. J.; Brunner, D.; Hen, R., Serotonin receptor 1A knockout: an animal model of anxiety-related disorder. Proc Natl Acad Sci U S A 1998, 95 (24), 14476-81.

160. Mayorga, A. J.; Dalvi, A.; Page, M. E.; Zimov-Levinson, S.; Hen, R.; Lucki, I., Antidepressant-like behavioral effects in 5-hydroxytryptamine(1A) and 5-hydroxytryptamine(1B) receptor mutant mice. J Pharmacol Exp Ther 2001, 298 (3), 1101-7.

161. Hepgul, N.; Cattaneo, A.; Zunszain, P. A.; Pariante, C. M., Depression pathogenesis and treatment: what can we learn from blood mRNA expression? BMC medicine 2013, 11 (1), 28.

162. Cattaneo, A.; Gennarelli, M.; Uher, R.; Breen, G.; Farmer, A.; Aitchison, K. J.; Craig, I. W.; Anacker, C.; Zunsztain, P. A.; McGuffin, P., Candidate genes expression profile associated with antidepressants response in the GENDEP study: differentiating between baseline 'predictors' and longitudinal 'targets'. Neuropsychopharmacology 2013, 38 (3), 377.

163. Katzav, A.; Solodeev, I.; Brodsky, O.; Chapman, J.; Pick, C. G.; Blank, M.; Zhang, W.; Reichlin, M.; Shoenfeld, Y., Induction of autoimmune depression in mice by anti-ribosomal $\mathrm{P}$ antibodies via the limbic system. Arthritis Rheum 2007, 56 (3), 938-48.

164. Köhler, O.; Benros, M. E.; Nordentoft, M.; Farkouh, M. E.; Iyengar, R. L.; Mors, O.; Krogh, J., Effect of anti-inflammatory treatment on depression, depressive symptoms, and adverse effects: a systematic review and meta-analysis of randomized clinical trials. JAMA psychiatry 2014, 71 (12), 1381-1391.

165. O'connor, J.; Lawson, M.; Andre, C.; Moreau, M.; Lestage, J.; Castanon, N.; Kelley, K.; Dantzer, R., Lipopolysaccharide-induced depressive-like behavior is mediated by indoleamine 2, 3-dioxygenase activation in mice. Molecular psychiatry 2009, 14 (5), 511. 
166. Miller, A. H.; Maletic, V.; Raison, C. L., Inflammation and its discontents: the role of cytokines in the pathophysiology of major depression. Biological psychiatry 2009, 65 (9), 732741.

167. Rajkowska, G.; Stockmeier, C. A., Astrocyte pathology in major depressive disorder: insights from human postmortem brain tissue. Curr Drug Targets 2013, 14 (11), 1225-36.

168. Rajkowska, G.; Miguel-Hidalgo, J., Gliogenesis and glial pathology in depression. CNS \& Neurological Disorders-Drug Targets (Formerly Current Drug Targets-CNS \& Neurological Disorders) 2007, 6 (3), 219-233.

169. Peuchen, S.; Bolaños, J. P.; Heales, S. J.; Almeida, A.; Duchen, M. R.; Clark, J. B., Interrelationships between astrocyte function, oxidative stress and antioxidant status within the central nervous system. Prog Neurobiol 1997, 52 (4), 261-281.

170. Anderson, C. M.; Nedergaard, M., Astrocyte-mediated control of cerebral microcirculation. Trends in neurosciences 2003, 26 (7), 340-344.

171. Benarroch, E. E. In Neuron-astrocyte interactions: partnership for normal function and disease in the central nervous system, Mayo Clinic Proceedings, Elsevier: 2005; pp 1326-1338.

172. Braun, K.; Antemano, R.; Helmeke, C.; Büchner, M.; Poeggel, G., Juvenile separation stress induces rapid region-and layer-specific changes in S100ß-and glial fibrillary acidic proteinimmunoreactivity in astrocytes of the rodent medial prefrontal cortex. Neuroscience 2009, 160 (3), 629-638.

173. Araya-Callís, C.; Hiemke, C.; Abumaria, N.; Flugge, G., Chronic psychosocial stress and citalopram modulate the expression of the glial proteins GFAP and NDRG2 in the hippocampus. Psychopharmacology 2012, 224 (1), 209-222.

174. Leventopoulos, M.; Rüedi-Bettschen, D.; Knuesel, I.; Feldon, J.; Pryce, C. R.; OpackaJuffry, J., Long-term effects of early life deprivation on brain glia in Fischer rats. Brain research 2007, 1142, 119-126.

175. Banasr, M.; Duman, R. S., Glial loss in the prefrontal cortex is sufficient to induce depressive-like behaviors. Biological psychiatry 2008, 64 (10), 863-870.

176. Lee, Y.; Son, H.; Kim, G.; Kim, S.; Lee, D. H.; Roh, G. S.; Kang, S. S.; Cho, G. J.; Choi, W. S.; Kim, H. J., Glutamine deficiency in the prefrontal cortex increases depressive-like behaviours in male mice. Journal of psychiatry \& neuroscience: JPN 2013, 38 (3), 183.

177. Cryan, J. F.; Dinan, T. G., Mind-altering microorganisms: the impact of the gut microbiota on brain and behaviour. Nature reviews neuroscience 2012, 13 (10), 701.

178. Mayer, E. A., Gut feelings: the emerging biology of gut-brain communication. Nature Reviews Neuroscience 2011, 12 (8), 453.

179. Selkrig, J.; Wong, P.; Zhang, X.; Pettersson, S., Metabolic tinkering by the gut microbiome: implications for brain development and function. Gut microbes 2014, 5 (3), 369-380. 180. Bercik, P.; Denou, E.; Collins, J.; Jackson, W.; Lu, J.; Jury, J.; Deng, Y.; Blennerhassett, P.; Macri, J.; McCoy, K. D., The intestinal microbiota affect central levels of brain-derived neurotropic factor and behavior in mice. Gastroenterology 2011, 141 (2), 599-609. e3.

181. Zheng, P.; Zeng, B.; Zhou, C.; Liu, M.; Fang, Z.; Xu, X.; Zeng, L.; Chen, J.; Fan, S.; Du, $\mathrm{X}$., Gut microbiome remodeling induces depressive-like behaviors through a pathway mediated by the host's metabolism. Molecular psychiatry 2016, 21 (6), 786.

182. Heijtz, R. D.; Wang, S.; Anuar, F.; Qian, Y.; Björkholm, B.; Samuelsson, A.; Hibberd, M. L.; Forssberg, H.; Pettersson, S., Normal gut microbiota modulates brain development and behavior. Proceedings of the National Academy of Sciences 2011, 108 (7), 3047-3052.

183. Bravo, J. A.; Forsythe, P.; Chew, M. V.; Escaravage, E.; Savignac, H. M.; Dinan, T. G.; Bienenstock, J.; Cryan, J. F., Ingestion of Lactobacillus strain regulates emotional behavior and central GABA receptor expression in a mouse via the vagus nerve. Proceedings of the National Academy of Sciences 2011, 201102999.

184. Savignac, H.; Kiely, B.; Dinan, T.; Cryan, J., B ifidobacteria exert strain-specific effects on stress-related behavior and physiology in BALB/c mice. Neurogastroenterology \& Motility 2014, 26 (11), 1615-1627.

185. Savignac, H.; Tramullas, M.; Kiely, B.; Dinan, T.; Cryan, J., Bifidobacteria modulate cognitive processes in an anxious mouse strain. Behavioural brain research 2015, 287, 59-72. 
186. Dinan, T. G.; Stanton, C.; Cryan, J. F., Psychobiotics: a novel class of psychotropic. Biological psychiatry 2013, 74 (10), 720-726.

187. Bornstein, S. R.; Schuppenies, A.; Wong, M. L.; Licinio, J., Approaching the shared biology of obesity and depression: the stress axis as the locus of gene-environment interactions. Mol Psychiatry 2006, 11 (10), 892-902.

188. Purcell, R. H.; Sun, B.; Pass, L. L.; Power, M. L.; Moran, T. H.; Tamashiro, K. L., Maternal stress and high-fat diet effect on maternal behavior, milk composition, and pup ingestive behavior. Physiol Behav 2011, 104 (3), 474-9.

189. Sharma, S.; Fulton, S., Diet-induced obesity promotes depressive-like behaviour that is associated with neural adaptations in brain reward circuitry. Int J Obes (Lond) 2013, 37 (3), 3829 .

190. Dong, C.; Sanchez, L. E.; Price, R. A., Relationship of obesity to depression: a familybased study. Int J Obes Relat Metab Disord 2004, 28 (6), 790-5.

191. Simon, G. E.; Von Korff, M.; Saunders, K.; Miglioretti, D. L.; Crane, P. K.; van Belle, G.; Kessler, R. C., Association between obesity and psychiatric disorders in the US adult population. Arch Gen Psychiatry 2006, 63 (7), 824-30.

192. Petrak, F.; Röhrig, B.; Ismail, K., Depression and Diabetes. In Endotext [Internet], MDText. com, Inc.: 2018.

193. Sakimura, K.; Maekawa, T.; Sasagawa, K.; Ishii, Y.; Kume, S. i.; Ohta, T., Depressionrelated behavioural and neuroendocrine changes in the Spontaneously Diabetic Torii (SDT) fatty rat, an animal model of Type 2 Diabetes Mellitus. Clinical and Experimental Pharmacology and Physiology 2018.

194. Aswar, U.; Chepurwar, S.; Shintre, S.; Aswar, M., Telmisartan attenuates diabetes induced depression in rats. Pharmacological reports 2017, 69 (2), 358-364.

195. Robinson, K. S.; Stewart, A. M.; Cachat, J.; Landsman, S.; Gebhardt, M.; Kalueff, A. V., Psychopharmacological effects of acute exposure to kynurenic acid (KYNA) in zebrafish. Pharmacol Biochem Behav 2013, 108, 54-60.

196. Dos Santos, M. M.; de Macedo, G. T.; Prestes, A. S.; Loro, V. L.; Heidrich, G. M.; Picoloto, R. S.; Rosemberg, D. B.; Barbosa, N. V., Hyperglycemia elicits anxiety-like behaviors in zebrafish: Protective role of dietary diphenyl diselenide. Prog Neuropsychopharmacol Biol Psychiatry 2018, 85, 128-135.

197. Willner, P.; Belzung, C., Treatment-resistant depression: are animal models of depression fit for purpose? Psychopharmacology 2015, 232 (19), 3473-3495.

198. Anreiter, I.; Sokolowski, H. M.; Sokolowski, M. B., Gene-Environment Interplay and Individual Differences in Behavior. Mind, Brain, and Education 2017, 0 (0).

199. Perani, C. V.; Slattery, D. A., Using animal models to study post-partum psychiatric disorders. British Journal of Pharmacology 2014, 171 (20), 4539-4555.

200. Lavi-Avnon, Y.; Weller, A.; Finberg, J. P.; Gispan-Herman, I.; Kinor, N.; Stern, Y.; Schroeder, M.; Gelber, V.; Bergman, S. Y.; Overstreet, D. H.; Yadid, G., The reward system and maternal behavior in an animal model of depression: a microdialysis study. Psychopharmacology (Berl) 2008, 196 (2), 281-91.

201. Petersen, A.; Wortwein, G.; Gruber, S. H.; Mathe, A. A., Escitalopram reduces increased hippocampal cytogenesis in a genetic rat depression model. Neurosci Lett 2008, 436 (3), 305-8.

202. Weiss, J. M.; Cierpial, M. A.; West, C. H., Selective breeding of rats for high and low motor activity in a swim test: toward a new animal model of depression. Pharmacol Biochem Behav 1998, 61 (1), 49-66.

203. West, C. H.; Weiss, J. M., A selective test for antidepressant treatments using rats bred for stress-induced reduction of motor activity in the swim test. Psychopharmacology (Berl) 2005, 182 (1), 9-23.

204. Okamoto, K.; Aoki, K., Development of a strain of spontaneously hypertensive rats. Jpn Circ J 1963, 27, 282-93.

205. Armario, A.; Gavalda, A.; Marti, J., Comparison of the behavioural and endocrine response to forced swimming stress in five inbred strains of rats. Psychoneuroendocrinology 1995, 20 (8), 879-90. 
206. El Yacoubi, M.; Vaugeois, J. M., Genetic rodent models of depression. Curr Opin Pharmacol 2007, 7 (1), 3-7.

207. Popa, D.; El Yacoubi, M.; Vaugeois, J. M.; Hamon, M.; Adrien, J., Homeostatic regulation of sleep in a genetic model of depression in the mouse: effects of muscarinic and 5-HT1A receptor activation. Neuropsychopharmacology 2006, 31 (8), 1637-46.

208. Bougarel, L.; Guitton, J.; Zimmer, L.; Vaugeois, J. M.; El Yacoubi, M., Behaviour of a genetic mouse model of depression in the learned helplessness paradigm. Psychopharmacology (Berl) 2011, 215 (3), 595-605.

209. Shumake, J.; Poremba, A.; Edwards, E.; Gonzalez-Lima, F., Congenital helpless rats as a genetic model for cortex metabolism in depression. Neuroreport 2000, 11 (17), 3793-8.

210. Overstreet, D. H.; Rezvani, A. H.; Knapp, D. J.; Crews, F. T.; Janowsky, D. S., Further selection of rat lines differing in 5-HT-1A receptor sensitivity: behavioral and functional correlates. Psychiatr Genet 1996, 6 (3), 107-17.

211. Commissaris, R. L.; Ardayfio, P. A.; McQueen, D. A.; Gilchrist, G. A., 3rd; Overstreet, D. H., Conflict behavior and the effects of 8-OHDPAT treatment in rats selectively bred for differential 5-HT(1A)-induced hypothermia. Pharmacol Biochem Behav 2000, 67 (1), 199-205.

212. File, S. E.; Ouagazzal, A. M.; Gonzalez, L. E.; Overstreet, D. H., Chronic fluoxetine in tests of anxiety in rat lines selectively bred for differential 5-HT1A receptor function. Pharmacol Biochem Behav 1999, 62 (4), 695-701.

213. Kromer, S. A.; Kessler, M. S.; Milfay, D.; Birg, I. N.; Bunck, M.; Czibere, L.; Panhuysen, M.; Putz, B.; Deussing, J. M.; Holsboer, F.; Landgraf, R.; Turck, C. W., Identification of glyoxalase-I as a protein marker in a mouse model of extremes in trait anxiety. $J$ Neurosci $\mathbf{2 0 0 5}$, 25 (17), 4375-84.

214. Bayne, K.; Wurbel, H., The impact of environmental enrichment on the outcome variability and scientific validity of laboratory animal studies. Revue scientifique et technique (International Office of Epizootics) 2014, 33 (1), 273-80.

215. Nader, J.; Claudia, C.; El Rawas, R.; Favot, L.; Jaber, M.; Thiriet, N.; Solinas, M., Loss of environmental enrichment increases vulnerability to cocaine addiction. Neuropsychopharmacology 2012, 37 (7), 1579.

216. Sáenz, J. C. B.; Villagra, O. R.; Trías, J. F., Factor analysis of forced swimming test, sucrose preference test and open field test on enriched, social and isolated reared rats. Behavioural brain research 2006, 169 (1), 57-65.

217. Hattori, S.; Hashimoto, R.; Miyakawa, T.; Yamanaka, H.; Maeno, H.; Wada, K.; Kunugi, H., Enriched environments influence depression-related behavior in adult mice and the survival of newborn cells in their hippocampi. Behavioural brain research 2007, 180 (1), 69-76.

218. Koh, S.; Magid, R.; Chung, H.; Stine, C. D.; Wilson, D. N., Depressive behavior and selective downregulation of serotonin receptor expression after early-life seizures: reversal by environmental enrichment. Epilepsy \& Behavior 2007, 10 (1), 26-31.

219. Wright, D.; Nakamichi, R.; Krause, J.; Butlin, R. K., QTL analysis of behavioral and morphological differentiation between wild and laboratory zebrafish (Danio rerio). Behavior genetics 2006, 36 (2), 271.

220. Wright, D.; Rimmer, L. B.; Pritchard, V. L.; Krause, J.; Butlin, R. K., Inter and intrapopulation variation in shoaling and boldness in the zebrafish (Danio rerio). Naturwissenschaften 2003, 90 (8), 374-7.

221. Dugatkin, L.; McCall, M.; Gregg, R.; Cavanaugh, A.; Christensen, C.; Unseld, M., Zebrafish (Danio rerio) exhibit individual differences in risk-taking behavior during predator inspection. Ethology Ecology \& Evolution 2005, 17 (1), 77-81.

222. Moretz, J. A.; Martins, E. P.; Robison, B. D., Behavioral syndromes and the evolution of correlated behavior in zebrafish. Behavioral ecology 2007, 18 (3), 556-562.

223. Volgin, A. D.; Yakovlev, O. V.; Demin, K. A.; Abreu, M. S. d.; Rosemberg, D. B.; Meshalkina, D. A.; Alekseeva, P. A.; Friend, A. J.; Amstislavskaya, T. G.; Kalueff, A. V., Understanding the Role of Environmental Enrichment in Zebrafish Neurobehavioral Models. Zebrafish 2018. 
224. Mathew, S. J.; Shah, A.; Lapidus, K.; Clark, C.; Jarun, N.; Ostermeyer, B.; Murrough, J. W., Ketamine for treatment-resistant unipolar depression. CNS drugs 2012, 26 (3), 189-204.

225. Berman, R. M.; Cappiello, A.; Anand, A.; Oren, D. A.; Heninger, G. R.; Charney, D. S.; Krystal, J. H., Antidepressant effects of ketamine in depressed patients. Biological psychiatry 2000, 47 (4), 351-354.

226. Zarate, C. A.; Singh, J. B.; Carlson, P. J.; Brutsche, N. E.; Ameli, R.; Luckenbaugh, D. A.; Charney, D. S.; Manji, H. K., A randomized trial of an N-methyl-D-aspartate antagonist in treatment-resistant major depression. Archives of general psychiatry 2006, 63 (8), 856-864.

227. Ibrahim, L.; Diazgranados, N.; Luckenbaugh, D. A.; Machado-Vieira, R.; Baumann, J.; Mallinger, A. G.; Zarate Jr, C. A., Rapid decrease in depressive symptoms with an N-methyl-daspartate antagonist in ECT-resistant major depression. Progress in Neuro-Psychopharmacology and Biological Psychiatry 2011, 35 (4), 1155-1159.

228. Murrough, J. W.; Iosifescu, D. V.; Chang, L. C.; Al Jurdi, R. K.; Green, C. E.; Perez, A. M.; Iqbal, S.; Pillemer, S.; Foulkes, A.; Shah, A., Antidepressant efficacy of ketamine in treatmentresistant major depression: a two-site randomized controlled trial. American Journal of Psychiatry 2013, 170 (10), 1134-1142.

229. Diazgranados, N.; Ibrahim, L.; Brutsche, N. E.; Newberg, A.; Kronstein, P.; Khalife, S.; Kammerer, W. A.; Quezado, Z.; Luckenbaugh, D. A.; Salvadore, G., A randomized add-on trial of an N-methyl-D-aspartate antagonist in treatment-resistant bipolar depression. Archives of general psychiatry 2010, 67 (8), 793-802.

230. Burgdorf, J.; Zhang, X.-1.; Nicholson, K. L.; Balster, R. L.; Leander, J. D.; Stanton, P. K.; Gross, A. L.; Kroes, R. A.; Moskal, J. R., GLYX-13, a NMDA receptor glycine-site functional partial agonist, induces antidepressant-like effects without ketamine-like side effects. Neuropsychopharmacology 2013, 38 (5), 729.

231. Carrier, N.; Kabbaj, M., Sex differences in the antidepressant-like effects of ketamine. Neuropharmacology 2013, 70, 27-34.

232. Gigliucci, V.; O’Dowd, G.; Casey, S.; Egan, D.; Gibney, S.; Harkin, A., Ketamine elicits sustained antidepressant-like activity via a serotonin-dependent mechanism. Psychopharmacology 2013, 228 (1), 157-166.

233. Koike, H.; Fukumoto, K.; Iijima, M.; Chaki, S., Role of BDNF/TrkB signaling in antidepressant-like effects of a group II metabotropic glutamate receptor antagonist in animal models of depression. Behavioural brain research 2013, 238, 48-52.

234. Koike, H.; Iijima, M.; Chaki, S., Effects of ketamine and LY341495 on the depressive-like behavior of repeated corticosterone-injected rats. Pharmacology Biochemistry and Behavior 2013, 107, 20-23.

235. Müller, H. K.; Wegener, G.; Liebenberg, N.; Zarate Jr, C. A.; Popoli, M.; Elfving, B., Ketamine regulates the presynaptic release machinery in the hippocampus. Journal of psychiatric research 2013, 47 (7), 892-899.

236. Walker, A. K.; Budac, D. P.; Bisulco, S.; Lee, A. W.; Smith, R. A.; Beenders, B.; Kelley, K. W.; Dantzer, R., NMDA receptor blockade by ketamine abrogates lipopolysaccharide-induced depressive-like behavior in C57BL/6J mice. Neuropsychopharmacology 2013, 38 (9), 1609.

237. Iijima, M.; Fukumoto, K.; Chaki, S., Acute and sustained effects of a metabotropic glutamate 5 receptor antagonist in the novelty-suppressed feeding test. Behavioural brain research 2012, 235 (2), 287-292.

238. Koike, H.; Iijima, M.; Chaki, S., Involvement of the mammalian target of rapamycin signaling in the antidepressant-like effect of group II metabotropic glutamate receptor antagonists. Neuropharmacology 2011, 61 (8), 1419-1423.

239. Liu, R.-J.; Fuchikami, M.; Dwyer, J. M.; Lepack, A. E.; Duman, R. S.; Aghajanian, G. K., GSK-3 inhibition potentiates the synaptogenic and antidepressant-like effects of subthreshold doses of ketamine. Neuropsychopharmacology 2013, 38 (11), 2268.

240. Yang, C.; Hu, Y.-M.; Zhou, Z.-Q.; Zhang, G.-F.; Yang, J.-J., Acute administration of ketamine in rats increases hippocampal BDNF and mTOR levels during forced swimming test. Upsala journal of medical sciences 2013, 118 (1), 3-8. 
241. Yang, C.; Li, X.; Wang, N.; Xu, S.; Yang, J.; Zhou, Z., Tramadol reinforces antidepressant effects of ketamine with increased levels of brain-derived neurotrophic factor and tropomyosinrelated kinase B in rat hippocampus. Frontiers of medicine 2012, 6 (4), 411-415.

242. Wang, X.; Yang, Y.; Zhou, X.; Wu, J.; Li, J.; Jiang, X.; Qu, Q.; Ou, C.; Liu, L.; Zhou, S., Propofol pretreatment increases antidepressant-like effects induced by acute administration of ketamine in rats receiving forced swimming test. Psychiatry Research 2011, 185 (1-2), 248-253.

243. Beurel, E.; Song, L.; Jope, R., Inhibition of glycogen synthase kinase-3 is necessary for the rapid antidepressant effect of ketamine in mice. Molecular psychiatry 2011, 16 (11), 1068.

244. Réus, G. Z.; Stringari, R. B.; Ribeiro, K. F.; Ferraro, A. K.; Vitto, M. F.; Cesconetto, P.; Souza, C. T.; Quevedo, J., Ketamine plus imipramine treatment induces antidepressant-like behavior and increases CREB and BDNF protein levels and PKA and PKC phosphorylation in rat brain. Behavioural brain research 2011, 221 (1), 166-171.

245. Li, N.; Lee, B.; Liu, R.-J.; Banasr, M.; Dwyer, J. M.; Iwata, M.; Li, X.-Y.; Aghajanian, G.; Duman, R. S., mTOR-dependent synapse formation underlies the rapid antidepressant effects of NMDA antagonists. Science 2010, 329 (5994), 959-964.

246. Ghasemi, M.; Raza, M.; Dehpour, A., NMDA receptor antagonists augment antidepressant-like effects of lithium in the mouse forced swimming test. Journal of Psychopharmacology 2010, 24 (4), 585-594.

247. Cruz, S. L.; Soberanes-Chávez, P.; Páez-Martinez, N.; López-Rubalcava, C., Toluene has antidepressant-like actions in two animal models used for the screening of antidepressant drugs. Psychopharmacology 2009, 204 (2), 279-286.

248. Engin, E.; Treit, D.; Dickson, C., Anxiolytic-and antidepressant-like properties of ketamine in behavioral and neurophysiological animal models. Neuroscience 2009, 161 (2), 359-369.

249. Rezin, G. T.; Gonçalves, C. L.; Daufenbach, J. F.; Fraga, D. B.; Santos, P. M.; Ferreira, G. K.; Hermani, F. V.; Comim, C. M.; Quevedo, J.; Streck, E. L., Acute administration of ketamine reverses the inhibition of mitochondrial respiratory chain induced by chronic mild stress. Brain research bulletin 2009, 79 (6), 418-421.

250. Garcia, L. S.; Comim, C. M.; Valvassori, S. S.; Réus, G. Z.; Barbosa, L. M.; Andreazza, A. C.; Stertz, L.; Fries, G. R.; Gavioli, E. C.; Kapczinski, F., Acute administration of ketamine induces antidepressant-like effects in the forced swimming test and increases BDNF levels in the rat hippocampus. Progress in neuro-psychopharmacology and biological psychiatry 2008, 32 (1), 140-144.

251. Hayase, T.; Yamamoto, Y.; Yamamoto, K., Behavioral effects of ketamine and toxic interactions with psychostimulants. BMC neuroscience 2006, 7 (1), 25.

252. Rosa, A. O.; Lin, J.; Calixto, J. B.; Santos, A. R. S.; Rodrigues, A. L. S., Involvement of NMDA receptors and L-arginine-nitric oxide pathway in the antidepressant-like effects of zinc in mice. Behavioural brain research 2003, 144 (1-2), 87-93.

253. Mantovani, M.; Pértile, R.; Calixto, J. B.; Santos, A. R.; Rodrigues, A. L. S., Melatonin exerts an antidepressant-like effect in the tail suspension test in mice: evidence for involvement of $\mathrm{N}$-methyl-D-aspartate receptors and the L-arginine-nitric oxide pathway. Neuroscience letters 2003, 343 (1), 1-4.

254. Denayer, T.; Stöhr, T.; Roy, M. V., Animal models in translational medicine: Validation and prediction. European Journal of Molecular \& Clinical Medicine 2014, 2 (1), 5.

255. Demin, K.; Meshalkina, D.; Lakstygal, A.; Kalueff, A., Developing translational biological psychiatry: learning from history to build the future. 2017.

256. Aragona, M., The role of comorbidity in the crisis of the current psychiatric classification system. Philosophy, Psychiatry, \& Psychology 2009, 16 (1), 1-11.

257. Aragona, M., The concept of mental disorder and the DSM-V. 2009.

258. Kato, T., A renovation of psychiatry is needed. World Psychiatry 2011, 10 (3), 198-199.

259. Gottesman, I. I.; Shields, J., Schizophrenia and genetics. A twin study vantage point. In ACAD. PRESS, NEW YORK, NY, 1972.

260. Gottesman, I. I.; Shields, J., Genetic theorizing and schizophrenia. The British Journal of Psychiatry 1973, 122 (566), 15-30. 
261. Gottesman, II; Gould, T. D., The endophenotype concept in psychiatry: etymology and strategic intentions. Am J Psychiatry 2003, 160 (4), 636-45.

262. Kalueff, A. V.; Ren-Patterson, R. F.; LaPorte, J. L.; Murphy, D. L., Domain interplay concept in animal models of neuropsychiatric disorders: a new strategy for high-throughput neurophenotyping research. Behav Brain Res 2008, 188 (2), 243-9.

263. Kalueff, A. V.; Stewart, A. M., Modeling neuropsychiatric spectra to empower translational biological psychiatry. Behav Brain Res 2015, 276, 1-7.

264. Kas, M. J.; Fernandes, C.; Schalkwyk, L. C.; Collier, D. A., Genetics of behavioural domains across the neuropsychiatric spectrum; of mice and men. Mol Psychiatry 2007, 12 (4), 324-30.

265. Crabbe, J. C.; Morris, R. G., Festina lente: late-night thoughts on high-throughput screening of mouse behavior. Nature neuroscience 2004, 7 (11), 1175.

266. Godinho, S. I.; Nolan, P. M., The role of mutagenesis in defining genes in behaviour. European journal of human genetics 2006, 14 (6), 651.

267. Tecott, L. H.; Nestler, E. J., Neurobehavioral assessment in the information age. Nature neuroscience 2004, 7 (5), 462.

268. Kalueff, A. V.; LaPorte, J. L.; Murphy, D. L.; Sufka, K., Hybridizing behavioral models: a possible solution to some problems in neurophenotyping research? Progress in NeuroPsychopharmacology and Biological Psychiatry 2008, 32 (5), 1172-1178.

269. Kalueff, A. V.; Aldridge, J. W.; LaPorte, J. L.; Murphy, D. L.; Tuohimaa, P., Analyzing grooming microstructure in neurobehavioral experiments. Nature protocols 2007, 2 (10), 2538.

270. Leussis, M. P.; Bolivar, V. J., Habituation in rodents: a review of behavior, neurobiology, and genetics. Neuroscience \& Biobehavioral Reviews 2006, 30 (7), 1045-1064.

271. Uhlhaas, P. J.; Singer, W., Neuronal dynamics and neuropsychiatric disorders: toward a translational paradigm for dysfunctional large-scale networks. Neuron 2012, 75 (6), 963-980.

272. Marsh, R.; Gerber, A. J.; Peterson, B. S., Neuroimaging studies of normal brain development and their relevance for understanding childhood neuropsychiatric disorders. Journal of the American Academy of Child \& Adolescent Psychiatry 2008, 47 (11), 1233-1251.

273. Kudryavtseva, N. N.; Bakshtanovskaya, I. V.; Koryakina, L. A., Social model of depression in mice of C57BL/6J strain. Pharmacol Biochem Behav 1991, 38 (2), 315-20.

274. Kudryavtseva, N., Peculiarities in forming agonistic behavior in mice using a sensory contact model. Review Novosibirsk: Institute of Cytology and Genetics SD RAS 1987.

275. Kudryavtseva, N.; Bakshtanovskaya, I., Development of depression like states in C57BL/6J submissive male mice (prepn'nt). Institute of Cytology and Genetics: Novosibirsk [in Russian] 1988.

276. Kudryavtseva, N.; Bakshtanovskaya, I.; Koryakina, L., Social model of depression in mice of C57BL/6J strain. Pharmacology Biochemistry and Behavior 1991, 38 (2), 315-320.

277. Avgustinovich, D.; Alekseenko, O.; Bakshtanovskaia, I.; Koriakina, L.; Lipina, T.; Tenditnik, M.; Kovalenko, I.; Kudriavtseva, N., Dynamic changes of brain serotonergic and dopaminergic activities during development of anxious depression: experimental study. Uspekhi fiziologicheskikh nauk 2004, 35 (4), 19-40.

278. Galyamina, A.; Kovalenko, I.; Smagin, D.; Kudryavtseva, N., Interaction of Depression and Anxiety in the Development of Mixed Anxiety/Depression Disorder. Experimental Studies of the Mechanisms of Comorbidity. Neuroscience and Behavioral Physiology 2017, 47 (6), 699-713. 279. Kola, I.; Landis, J., Can the pharmaceutical industry reduce attrition rates? Nature reviews Drug discovery 2004, 3 (8), 711.

280. Pangalos, M. N.; Schechter, L. E.; Hurko, O., Drug development for CNS disorders: strategies for balancing risk and reducing attrition. Nature Reviews Drug Discovery 2007, 6 (7), 521.

281. Choi, D. W.; Armitage, R.; Brady, L. S.; Coetzee, T.; Fisher, W.; Hyman, S.; Pande, A.; Paul, S.; Potter, W.; Roin, B., Medicines for the mind: policy-based "Pull" incentives for creating breakthrough CNS drugs. Neuron 2014, 84 (3), 554-563. 
282. Maniam, J.; Morris, M. J., Long-term postpartum anxiety and depression-like behavior in mother rats subjected to maternal separation are ameliorated by palatable high fat diet. Behav Brain Res 2010, 208 (1), 72-9.

283. Pryce, C. R.; Ruedi-Bettschen, D.; Dettling, A. C.; Weston, A.; Russig, H.; Ferger, B.; Feldon, J., Long-term effects of early-life environmental manipulations in rodents and primates: Potential animal models in depression research. Neurosci Biobehav Rev 2005, 29 (4-5), 649-74.

284. Ivy, A. S.; Rex, C. S.; Chen, Y.; Dube, C.; Maras, P. M.; Grigoriadis, D. E.; Gall, C. M.; Lynch, G.; Baram, T. Z., Hippocampal dysfunction and cognitive impairments provoked by chronic early-life stress involve excessive activation of CRH receptors. J Neurosci 2010, 30 (39), 13005-15.

285. Rice, C. J.; Sandman, C. A.; Lenjavi, M. R.; Baram, T. Z., A novel mouse model for acute and long-lasting consequences of early life stress. Endocrinology 2008, 149 (10), 4892-900.

286. Sudo, N.; Chida, Y.; Aiba, Y.; Sonoda, J.; Oyama, N.; Yu, X. N.; Kubo, C.; Koga, Y., Postnatal microbial colonization programs the hypothalamic-pituitary-adrenal system for stress response in mice. The Journal of physiology 2004, 558 (1), 263-275.

287. Leith, N. J.; Barrett, R. J., Effects of chronic amphetamine or reserpine on self-stimulation responding: Animal model of depression? Psychopharmacology 1980, 72 (1), 9-15.

288. Sethy, V. H.; Hodges Jr, D. H., Antidepressant activity of alprazolam in a reserpineinduced model of depression. Drug development research 1985, 5 (2), 179-184.

289. Piato, A. L.; Rosemberg, D. B.; Capiotti, K. M.; Siebel, A. M.; Herrmann, A. P.; Ghisleni, G.; Vianna, M. R.; Bogo, M. R.; Lara, D. R.; Bonan, C. D., Acute restraint stress in zebrafish: behavioral parameters and purinergic signaling. Neurochem Res 2011, 36 (10), 1876-86.

290. Piato, A. L.; Capiotti, K. M.; Tamborski, A. R.; Oses, J. P.; Barcellos, L. J.; Bogo, M. R.; Lara, D. R.; Vianna, M. R.; Bonan, C. D., Unpredictable chronic stress model in zebrafish (Danio rerio): behavioral and physiological responses. Prog Neuropsychopharmacol Biol Psychiatry 2011, 35 (2), 561-7.

291. Saszik, S. M.; Smith, C. M., The impact of stress on social behavior in adult zebrafish (Danio rerio). Behavioural pharmacology 2018, 29 (1), 53-59.

292. Kato, T.; Kubota, M.; Kasahara, T., Animal models of bipolar disorder. Neurosci Biobehav Rev 2007, 31 (6), 832-42.

293. Kyzar, E.; Stewart, A. M.; Landsman, S.; Collins, C.; Gebhardt, M.; Robinson, K.; Kalueff, A. V., Behavioral effects of bidirectional modulators of brain monoamines reserpine and damphetamine in zebrafish. Brain Res 2013, 1527, 108-16.

294. Wang, Y.; Liu, W.; Yang, J.; Wang, F.; Sima, Y.; Zhong, Z. M.; Wang, H.; Hu, L. F.; Liu, C. F., Parkinson's disease-like motor and non-motor symptoms in rotenone-treated zebrafish. Neurotoxicology 2017, 58, 103-109.

295. Li, X.; Liu, X.; Li, T.; Li, X.; Feng, D.; Kuang, X.; Xu, J.; Zhao, X.; Sun, M.; Chen, D., $\mathrm{SiO} 2$ nanoparticles cause depression and anxiety-like behavior in adult zebrafish. RSC Advances 2017, 7 (5), 2953-2963.

296. Ziv, L.; Muto, A.; Schoonheim, P. J.; Meijsing, S. H.; Strasser, D.; Ingraham, H. A.; Schaaf, M. J.; Yamamoto, K. R.; Baier, H., An affective disorder in zebrafish with mutation of the glucocorticoid receptor. Mol Psychiatry 2013, 18 (6), 681-91.

297. Griffiths, B. B.; Schoonheim, P. J.; Ziv, L.; Voelker, L.; Baier, H.; Gahtan, E., A zebrafish model of glucocorticoid resistance shows serotonergic modulation of the stress response. Front Behav Neurosci 2012, 6, 68. 